MÉSZÁROS István László

DOI: 10.15170/DIKE.2020.04.01.14

adjunktus, rektorhelyettes ${ }^{1}$

Szent Pál Akadémia

\title{
A san remoi megállapodás századik évfordulójára A modern zsidó állam nemzetközi jogi alapjairól
}

\section{For the Centenary of the San Remo Resolution - About the International Law Foundations of the Modern Jewish State}

The international law foundations of the modern Jewish State date back to the Resolution of the San Remo Peace Conference in 1920. This Conference transformed the aspiration of reconstituting the Jewish national home in its ancestral territory Palestine into a binding international agreement, setting the stage for the posterior League of Nations Mandate for Palestine in 1922. The Mandate as a legally binding international treaty based on the now hundred years old Resolution assigned the whole land from the line of the River Jordan to the Mediterranean Sea for the Jewish national home. Thus, it is not all the same, whether the international law foundations of the modern Jewish statehood are derived from only the United Nations General Assembly's "Partition Plan" of 1947 or former international law agreements. This study aims to outline the consequences of the San Remo agreement in the past century.

Keywords: San Remo Resolution, partition of the Ottoman Empire, Israel, Judea and Samaria, mandate for Palestine, Transjordan Memorandum, UNpartition plan 1947, Oslo Accords

\section{A san remoi megállapodás nemzetközi jogi jelentősége}

Száz éve, 1920 áprilisában az itáliai San Remoban született meg az a nemzetközi megállapodás, amelyben az első világháborúban győztes Szövetséges Főhatalmak Tanácsa a zsidó nemzeti otthon Palesztinában való helyreállításáról döntött. Nagy-Britannia, Franciaország, Olaszország és Japán akik egyben az ENSZ elődjeként megalapított Népszövetség vezető szervét képező Tanács állandó tagságát is alkották - a megfigyelőként jelenlévő Amerikai Egyesült Államok mellett ezen az 1920. április 19. és 26. között lezajlott konferencián állapodtak meg az Oszmán Birodalom uralma alól felszabadult közel-keleti térség helyzetének rendezéséről. Ennek a megállapodásnak a Népszövetség általi elfogadásával került Palesztina és Mezopotámia brit, a későbbi Szíria és Libanon területe pedig francia mandátumi igazgatás alá abból a célból, hogy a megbízott hatalmak közreműködésével ezeken a területeken belátható időn belül megteremtődjenek az önállósodás politikai, közigazgatási és gazdasági feltételei. Palesztina specialitását az képezte, hogy ott kifejezetten a zsidó nemzeti otthon helyreállítását tűzték ki célként.

\footnotetext{
1 Ügyvéd, 1990 és 1998 között az Országgyúlés Emberi Jogi Bizottságának alelnöke, 1994 és 1995 között az Alkotmányügyi, Törvényelőkészítő és Igazságügyi Bizottságának, majd 1996 és 1998 között az Európai Integrációs Ügyek Bizottságának tagja, 1994 és 1998 között az Európa Tanács Parlamenti Közgyűlése Jogi Bizottságának tagja.
} 
A mintegy kétezer éve elvesztett zsidó államiság feltámasztása szempontjából nem csak politika- és jogtörténeti, hanem máig ható nemzetközi jogi jelentősége van a san remoi megállapodásnak. Ez a megkötésében részes felek viszonylatában már önmagában is nemzetközi jogi kötelezettséget rögzítő megegyezés nemzetközi jogi rangra emelte a zsidó nemzeti otthon helyreállitásának célját egykori földrajzi helyén, Palesztinában, és ezt a létrehozandó palesztinai népszövetségi mandátum kifejezett feladatává avatta. Ugyanakkor a török uralom alól felszabaduló arabok jogait is megalapozta azzal, hogy részükre az összes többi közel-keleti mandátum területén előirányozta önálló államiságuk perspektíváját, a helyreállítandó zsidó nemzeti otthonban pedig polgári és vallási jogaik védelmét.

A jelen tanulmány a san remoi megállapodás létrejötte óta eltelt száz évben annak következményeit kívánja felvázolni azzal a céllal, hogy - az egyébként teljes mértékben átpolitizált téma - történeti és nemzetközi jogi alapjaira rávilágítson.

\section{A nemzeti otthon létrehozásának történeti és nemzetközi jogi alapjai}

\subsection{Az ókori zsidó állam}

Az ősi zsidó állam koráig témánk tekintetében azért szükséges visszapillantani, mert az Imperium Romanum hódítása következtében megszületett terület-átnevezés mintegy a zsidóságra terheli annak bizonyítását, hogy milyen jogon formál bármilyen igényt erre a területre. A szóban forgó térségben, Kánaán földjén Kr.e. több mint ezer évvel ${ }^{2}$ alapították meg önálló államukat a honfoglaló zsidó törzsek.

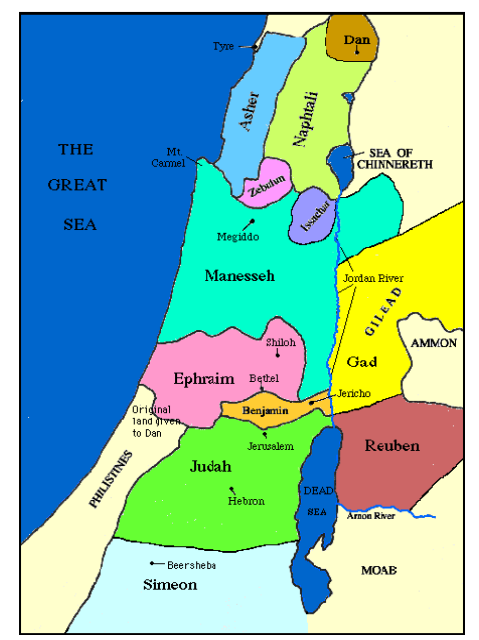

1. kép: A honfoglalás kora: a zsidó törzsek letelepedése ${ }^{3}$

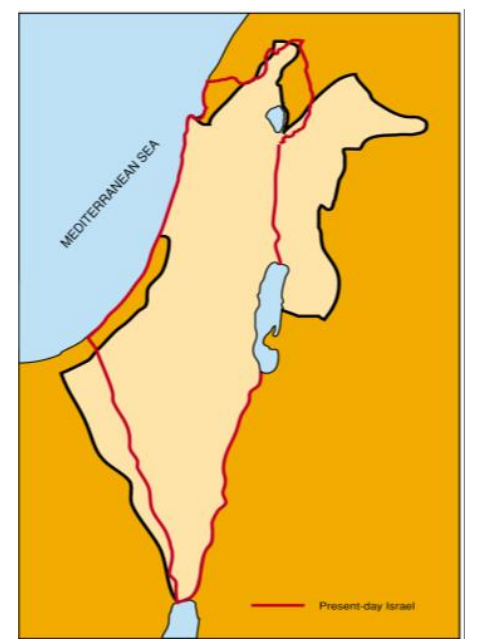

2. kép: Dávid és Salamon királysága (Kr.e 10. sz.) $)^{4}$

\footnotetext{
2 A honfoglalás időpontjának meghatározásánál többféle számítás létezik: a bibliai adatok alapján a Kr.e. 15. századról beszélnek, ezzel szemben az úgynevezett „alacsony datálás” képviselői a 13. század mellett foglalnak állást. Témakörünk szempontjából ennek nincsen jelentősége, a lényeg az, hogy történetileg először önálló és egységes egésszé a terület zsidó állam formájában került megszervezésre.

3 A kép forrása: https://www.jewishvirtuallibrary.org/map-of-the-twelve-tribes-of-israel-2. Copyright AmericanIsraeli Cooperative Enterprise - Reprinted with permission (a továbbiakban: ( ) AICE).

${ }^{4}$ A képen a piros vonal a mai határokat jelöli. Forrás: https://www.jewishvirtuallibrary.org/map-of-the-kingdom-ofdavid-and-solomon (๑ AICE).
} 
A Kr.e. 8. és 6. században lezajlott asszír, majd babiloni hódítás átmeneti időre véget vetett ugyan a kettészakadt (Izrael és Júda királysága) zsidó államiságnak, azonban a makkabeusi szabadságharc eredményeként az államiság a Kr.e. 2. században helyreállt. E periódus aztán a lépcsőzetes római hódítás miatt ért véget, ami először a római befolyás érvényesülésében, majd Iudea provinciává szervezésében, végül magának a nemzeti otthonnak a fölszámolásában jelent meg. ${ }^{5}$ Ez utóbbit a római megszállás ellen Kr.u. 66-ban kitört felkelés váltotta ki, amelyet a rómaiak vérbefojtottak. Ennek során rombolták le Jeruzsálemben a zsidó a Templomot, amit azóta sem építettek újjá. A Hadrianus császár idejében 132 és 135 között lezajlott újabb felkelés, a Bar-Kochba vezette szabadságharc leverése után a római császár elhatározta, hogy végleg leszámol a zsidókkal. A megtorlás során Iudea zsidó lakosságának életben maradt része elmenekült, vagy rabszolgának adták el. Avégett, hogy még a zsidóság emlékezetét is teljesen eltöröljék a térségben, Jeruzsálem elnevezését a császár neve (Aelius Hadrianus) után Aelia Capitolina névre változtatták, míg a provincia új neve Syria Palaestina lett. Ekkortól terjedt el - máig is éreztetve hatását - a Palesztina elnevezés, amelyet a zsidók ősi ellenségei, a filiszteusok lakta földrészlet nevéből (Filisztea) kreáltak annak ellenére, hogy ilyen elnevezéssel azelőtt sosem illették a Földközi-tenger és a Jordán folyó közé esô teljes területet, csak annak az egykori filiszteus településeket (Gáza, Askelon, Asdod, Ekron, Gáth) felölelő, délnyugati tengerparti sávját. ${ }^{6}$

Izrael földje 614-ig a Római Birodalom, illetve 395-től a Keletrómai Birodalom uralma alatt állt. Ezt a perzsa szasszanida (614-629), majd a korai muszlim arab hódítás (636-1099) időszaka követte. Az utóbbi alatt, 691-ben építették fel a Szikladómot a jeruzsálemi Templom-hegyen az egykori zsidó Templom helyén, amit rövidesen ugyanitt az Al-Aksza mecset felállítása követett. A keresztesek az I. keresztes hadjárat során 1099-ben bevették Jeruzsálemet és megalapították a Jeruzsálemi Királyságot (Regnum Hierosolimitanum) hozzávetőleg a mai Izraelnek és Libanonnak megfelelő területen. A királyság 1291-ig állt fenn, amikor a mameluk szultán, al-Ashraf Khalil elfoglalta az utolsó, keresztes kézen lévő várost, Akkót is. Ezt 1517-ben az oszmán-török hódoltság váltotta, ami négyszáz éven át, egészen az első világháború végéig tartott. Palesztina és ezen belül Jeruzsálem azonban a muszlim fennhatóság hosszú időtartama ellenére sem vált soha központi fontosságú hellyé sem az iszlám vallás, sem pedig a muszlim birodalmak számára. Jeruzsálem neve egyszer sem szerepel a Koránban. Mekkával és Medinával ellentétben ide nem irányult jelentős muszlim vallási zarándoklat, és a keresztesek középkori királyságának kivételével Jeruzsálemet sosem tette meg egyetlen meghódítója sem fővárosának, egyikük sem létesített önálló államot az úgynevezett Palesztinában. A zsidó jelenlét azonban a szétszóratás idején sem szűnt meg teljesen a Szentföldön. Kis létszámban bár, de voltak, akik a viszontagságok ellenére folyamatosan kitartottak ott. Jelenlétük főként a galileai Tibériáshoz és Cfáthoz, továbbá a júdeai Hebronhoz és - miután a rómaiak szigora valamelyest enyhült - Jeruzsálemhez kötődött, ${ }^{7}$ és a szétszóratásban élő

\footnotetext{
5 Pompeius palesztinai hadjáratát (Kr.e. 63) illetve területi rendezéseit (Kr.e. 63-55) Vespasianus galileai és iudeai hadjáratát, Jeruzsálem (70) és Massada (73) elfoglalását, illetve a Bar-Kochba felkelést (131-135) lásd AHARONI - AVIYONAH, Bibliai atlasz 159-197.

${ }^{6}$ LEwIN, The archaeology of Ancient Judea and Palestine 33; BEN-SAsson, A History of the Jewish People 334. Az ókori zsidó állam történetéhez magyarul lásd GRÜLL, Bibliai történelem; GrÜLL, Áruló vagy megmentő; GRÜLL, „Ézsau három könnycseppje”.

${ }^{7}$ Az adatokat az egyes korszakokban (636-1880 és 1880-1914) lásd GILBERT, The Routledge Atlas of the Arab-Israeli Conflict 2-3.
} 
zsidóság körében is folyamatosan fennmaradt a szándék az ősök földjére való hazatérésre. A nép, mint az önálló államisághoz szükséges egyik feltétel az évszázadok során nem veszett el.

\subsection{A bázeli programtól a Cambon- és a Balfour-szándéknyilatkozatig}

Herzl Tivadar (1860-1904) álmának, a zsidó állam újraszervezésének megvalósulásában az egyik első lépés a Bázelben megrendezett I. Cionista Világkongresszus (1897) volt. A kongresszus által elfogadott nyilatkozatban a Heræl által életre hívott mozgalomnak világos utat jelöltek ki: „A cionizmus célja, hogy a zsidó nép számára közjogilag szavatolt otthont teremtsen Palesztinában”."

Heræ̨l halála után mintegy másfél évtizeddel a mozgalomnak sikerült a francia, majd a brit kormány támogatását is megnyernie a hazatérés programjához. Jules-Martin Cambon, a francia kormány külügyminisztere 1917. június 4-én kelt levelében, melyet Nahum Sokolowhoz, a Cionista Világszervezet végrehajtó bizottsága főtitkárához intézett, a következőképp fogalmazott: „Ön úgy véli, hogy amennyiben a körülmények lehetövé teszik (...) az igazság beteljesedését és a sérelmek orvoslását jelentené annak elómozditása a Szövetséges Hatalmak védnöksége alatt, hogy a zsidó nemzetiség úijászülethessen azon a földön, amelyröl népét oly soke évszázaddal ezelött elürték. A francia kormány, amely azért lépett be a jelenlegi háborúba, hogy egy igazságtalanul megtámadott népet védelmébe vegyen, samely tovább folytatja a harcot, hogy a jó gyözedelmeskedhessék a rossz felett, feltétlenül rokonsz̨envezilk az Ön által képviselt üggyel, amelynek sikere elszakithatatlanul kapcsolódik a Szövetségesek által képviselt ügy gyözelméhez. (...)”."

Öt hónappal később, 1917. november 2-án Arthur James Balfour brit külügyminiszter kormánya nevében a következőképp nyilatkozott: „Kedves Lord Rotschild! Örömmel adom tudtára Öfelsége kormánya nevében az alábbi rokonszenv nyilatkozatot a cionista törekvések mellett, amely a kabinet számára elöterjesztésre és általa elfogadásra került: Öfelsége kormánya kedvezốn vélekedik egy nemzeti otthon (,national bome”) létesitéséröl a zsidó nép squámára Palesztinában, és legjobb igyekezetével azon leš, hogy e cél valóra váltását megkönnyitse, világossá téve ugyanakkor, hogy nem kerülhet sor semmiféle olyan lépésre, amely sértené a már meglévő palesżtinai nem zsidó kö̃össégek polgári és vallási jogait, vagy bármely más országban élö zsidók jogait és politikai státuszát. Hálás volnék, ha ež a nyilatkozatot ismertetné a Cionista Szövetséggel."

Cambon és Balfour kormányuk nevében megfogalmazott levelei még csak politikai szándéknyilatkozatok voltak, tehát nem jelentettek jogi kötelezettségvállalást. Ennek ellenére jelentőségük rendkívüli, mivel az akkori két legbefolyásosabb európai nagyhatalom politikai támogatásáról volt szó. Olyan állásfoglalásról, ami a zsidóság népként, ráadásul nemzeti otthonra jogosult népként való elismerését és egy konkrét földrajzi helyhez, Palesztinához való történelmi kötődésének elismerését jelenti.

\subsection{A san remoi megállapodás}

Pár évvel később a politikai szándékból nemzetközi jogi aktus lett. Az első világháborút lezáró párizsi békekonferencián felállított Népszövetség 1919. június 28-án elfogadott Egyezségokmánya

\footnotetext{
8 A bázeli program pontjait és annak magyar fordítását lásd https://www.jewishvirtuallibrary.org/first-zionistcongress-and-basel-program-1897 és Dokumentumok a Közel-Kelet XX. századi történetéhez 21.

${ }^{9}$ Cambon levelét magyar fordításban lásd Dokumentumok a Közel-Kelet XX. századi történetéhez 41.

${ }^{10}$ Balfour levelét magyar fordításban lásd Dokumentumok a Közel-Kelet XX. századi történetéhez 46.
} 
arról rendelkezett (22. cikkely), hogy a török és német uralom alól felszabadított korábbi gyarmatokat a Népszövetség felügyelete alá vonják, amely ezt oly módon látja el, hogy egyes győztes hatalmaknak megbízást (mandátumot) ad a kérdéses területek igazgatására. A gyámságot azzal indokolták, hogy az érintett területeken lakó népek „a mai világ különösen nehézz viszonyai köozött még nem tudják önmagukat kormányozni”. ${ }^{11}$ A területeket - lakosságuk "fejlódési foka”, földrajzi fekvése és gazdasági viszonyai alapján - három kategóriába sorolták. Ezek közül az „A” kategóriába olyan területek tartoztak, amelyek már elérték a fejlődésnek azt a szintjét, amelyre tekintettel képesek úgynevezett félszuverén államként múködni az igazgatásukkal megbízott hatalom hathatós közremúködésével addig, amíg önálló lábra állhatnak, azaz szuverén állammá válhatnak. Az „A” kategóriába elsősorban az Oszmán Birodalomtól elcsatolt területek - köztük Palesztina - tartozott.

E kört illetően a következő év tavaszán, 1920. április 19 - április 26. között az olaszországi San Remoban konkretizálta a Szövetséges Főhatalmak Tanácsa ${ }^{12}$ a létrehozandó népszövetségi mandátumokat. Ennek keretében a palesztinai mandátum céljául a Balfour-nyilatkozat megvalósítását szabták, azaz a zsidó nemzeti otthon létrehozását tették a mandátum kezelójének feladatává: „A Magas Szerzốdő Felek megállapodnak abban, bogy a 22. cikkeely ${ }^{13}$ rendelkeezéseinek alapján Palesżtina igazgatását a Szövetséges Föhatalmak által megállapitandó (földrajzi) határok közööt az általuk kiválasztott Megbizottra bizzák. A Megbizott felelös lesz az eredetileg a Brit Kormány által 1917. november 8án (sic!) kiadott, és a többi Szövetséges Hatalom által elfogadott Nyilatkozat végrehajtásáért, Palesztinában nemzeti otthon létesitéséert a zsidó nép számára, világossá téve, hogy nem kerülhet sor semmiféle olyan lépésre, amely sértené a már meglévö palesztinai nem zsidó közössségek polgári és vallási jogait, vagy bármely más országban éló zsidók jogait és politikai státuszát." "14

San Remoban tehát nemzetközi jogi rangra emelték a Balfour-nyilatkozatot azzal, hogy annak tartalmát belefoglalták a nemzetközi megállapodásba, mint a létrehozandó palesztinai mandátum jogalapját és célját. A győztes hatalmak nemzetközi jogi érvénnyel kötelezték el magukat egy a mandátumi igazgatás alatt szuverén állammá érlelendő zsidó nemzeti otthon Palesztinában való megteremtése mellett. ${ }^{15}$ A konferencia határozata szerint a mandátum-szerződéseket - a Szövetséges Főhatalmak általi konkrét megszövegezést követően - a Népszövetség elé kell terjeszteni elfogadásra. Ennek a folyamatnak az eredményeként Mezopotámia (Irak) és Palesztina brit, Libanon és Szíria pedig francia mandátummá vált. ${ }^{16}$

A san remoi megállapodás kötőerejét bizonyítja, hogy rá való tekintettel a Balfour-nyilatkozat bekerült a Törökországgal 1920. augusztus 10-én Sévres-ben aláirásra került békeszerződésbe,

\footnotetext{
${ }^{11}$ Magyar fordításban lásd Dokumentumok a Közel-Kelet XX. századi történetéhez 60-61.

12 A delegációkat David Lloyd George brit miniszterelnök, Alexandre Millerand francia miniszterelnök, Francesco Nitti olasz miniszterelnök, Keisiro Macui japán nagykövet, valamint Robert Johnson amerikai nagykövet vezette.

${ }^{13}$ A Népszövetség Egyezségokmányának vonatkozó cikkelyére történt utalás.

14 Resolution at San Remo, https://www.jewishvirtuallibrary.org/the-san-remo-conference; Minutes of Palestine Meeting of the Supreme Council of the Allied Powers held in San Remo at the Villa Devachan, https://commons.wikimedia.org/wiki/File:Minutes_of_the_1920_Conference_of_San_Remo.pdf.

${ }^{15}$ Az értékelést lásd GRIEF, The Legal Foundation and Borders of Israel under International Law 18-44; STEIN, The Balfour Declaration 652 - 663.; LLOYD GEORGE, The Truth About the Peace Conference 1167-1175.

${ }^{16}$ A mezopotámiai mandátumot végül nem alapították meg hivatalosan, helyette brit fennhatóság alatt egyből az Iraki Királyság alakult meg, amely fölött az 1922-ben kötött iraki-brit együttműködési szerződés biztosította a brit primátust. Irak 1932-ben, Libanon 1943-ban, Szíria ténylegesen 1946-ban, nyerte el függetlenségét.
} 
amely az Oszmán Birodalmat darabolta fel. ${ }^{17}$ A szerződés 95. cikkelye rögzítette, hogy „a Nemz̨etek Szövetsége Egyezségokmányának. 22. cikkelyében foglaltak alapján Palesztina körigazgatását a Szövetséges Fóhatalmak rögzítette határok között, az emlitett Hatalmak által kiválasztott Megbizott Hatalomra rubázzák. A Megbizott Hatalom felelós lesz a brit kormány 1917. november 2-án kibocsátott, s a többi Szövetséges hatalom által is elfogadott nyilatkozatának (értsd: a Balfour-nyilatkozat) végrehajtásáért (...)”." ${ }^{18}$ Ez a szerződés azonban a kirobbanó török függetlenségi háború miatt nem lépett hatályba.

Az újratárgyalás eredményeként 1923. július 24-én újabb békeszerződés született Lausanneben. Ebből már kimaradt a Palesztinára való konkrét utalás, mert időközben - 1922. július 24-én elfogadást nyert a népszövetségi mandátumszerződés, amelyben a Népszövetség Palesztina kormányzásával és igazgatásával Nagy-Britanniát bízta meg. Emiatt utólag fölöslegessé vált a brit mandátum tartalmáról a békeszerződésben külön is rendelkezni, így az egy általános utalással erôsíti meg azt: „Törökország ezennel lemond minden jogáról és jogciméröl azon terïletek vonatkozásában, amelyek a jelen Szerzödés által lefektetett határokon kivül esnek (...) ezen terïletek jövöjét az érintett Felek rendezike el $(\ldots)^{\prime 19}$

\subsection{A palesztinai brit népszövetségi mandátum}

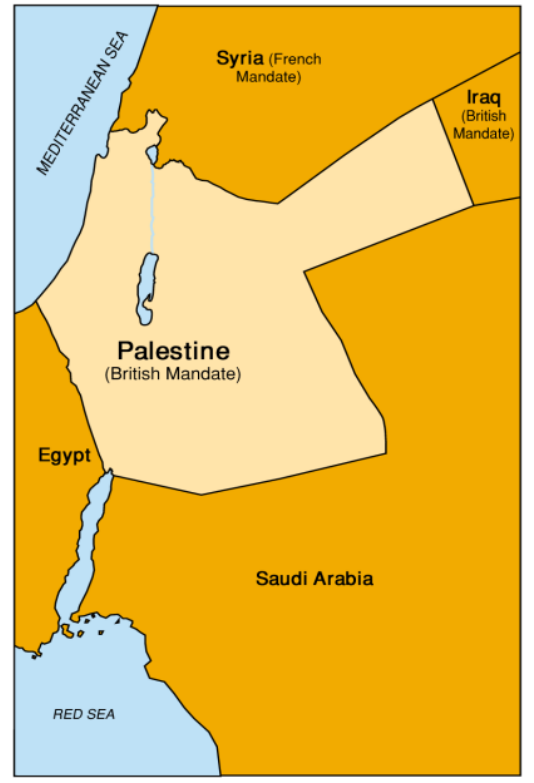

A san remoi megállapodás folyományaként elfogadott palesztinai brit népszövetségi mandátumszerződés, ${ }^{20}$ ami már a mandátumterület határait is pontosította, az akkor 51 tagállamból álló Népszövetség nemzetközi szerződése volt, így minden féllel szemben nemzetközi jogi kötőerôvel bírt. Az Amerikai Egyesült Államok - amely nem volt tagja a Népszövetségnek - maga is elismerte a szerződést a NagyBritanniával 1924-ben kötött megállapodásában. ${ }^{21}$ A szerződés deklarált célja a „zsidó nemzeti otthon visszaállitása” volt „Palesżtinában”, amelyhez a zsidó népet „történelmi kapcsolat” füzi. A 28 cikkelyből álló szerződés a preambulumában megismételte a Balfour-nyilatkozatban rögzített célokat és kimondta, hogy „ezáltal elismerést nyert a zisidó népnek Palesztinával való történelmi kapcsolata, valamint nemzeti otthona visszaállitásának alapelve”.

3. kép: A palesztinai brit mandátum területe ${ }^{22}$

\footnotetext{
${ }^{17}$ Helmreich, From Paris to Sèvres. The partition of the Ottoman Empire, passim.

${ }^{18}$ Magyar fordításban lásd Dokumentumok a Közel-Kelet XX. századi történetéhez 84.

${ }^{19}$ A békeszerződés 16. cikkelyét lásd Dokumentumok a Közel-Kelet XX. századi történetéhez 108.

20 The Palestine Mandate, https://avalon.law.yale.edu/20th_century/palmanda.asp, magyarul lásd Dokumentumok a Közel-Kelet XX. századi történetéhez 100-104. Ugyan a szerződést 1922. július 24-én fogadta el a Népszövetség, hatályba csak 1923. szeptemberben lépett, a végleges, lausanne-i török békeszerződés megkötése után.

21 The Anglo American Treaty of 1924, http://israelinternationallaw.blogspot.com/2015/12/the-anglo-americantreaty-of-1924.html. Az Amerikai Egyesült Államok eleve elismerte a mandátumszerződést megalapozó san remoi megállapodást is, melynek elfogadásán maga is részt vett megfigyelőként.

${ }^{22}$ A kép forrása: https://www.jewishvirtuallibrary.org/map-of-jewish-national-home-determined-by-san-remoconference-1920 (๔ AICE).
} 
Jelentősége van annak, hogy a szerződés a zsidó nemzeti otthon „visszaállitásáról” (reconstitution) beszélt, nem pusztán a megteremtésérôl. Így deklarálta, hogy a zsidóság nemzeti otthona a nemzetközi szervezet által elismert, létező, történelmi jogon alapul, nem pedig magából a mandátumból ered. A mandátum célja éppen az volt, hogy ezt a jogot garantálja és érvényesülését előmozdítsa Palesztinában: a szerződés 2. cikkelye kötelezettségként rögzítette, hogy „a Megbízott Hatalom felelös olyan politikai, közigazgatási és gazdasági feltételek megteremtéséert, amelyek biz̨tositják a zsidó nemzeti otthon felállitását a bevezetésben (preambulumban) megállapitott elvek alapján, továbbá gondozza az. önkormány zó intézmények fejlesztését és valamennyi palesztinai lakos polgári és vallási jogainak védelmét, fajra és vallásra tekintet nélkül."

A nemzeti otthonnak ebben a szerződésben nemzeti közösségként egyetlen kedvezményezettje a zsidó nép volt. Ez azt jelentette, hogy a mandátumszerződés kifejezetten csak a zsidóság számára előlegezte meg a szuverén nemzetállam megformálásának jogát a mandátum távlati céljaként az erre kijelölt mandátumi területen azzal a preambulumban megfogalmazott megszoritással, hogy „semmi sem történhet a Palesztinában meglevő nem zsidó közösségek polgári és vallási jogainake, vagy más országbeli zsidók jogainak és politikai státuszának sérelmére”. A majdani szuverén zsidó nemzetállamban tehát garantálni kell az ott élő nem zsidó lakosság tagjainak a polgári és vallási jogait is, ami azonban magától értetődően nem - a fô célul kitűzött zsidó államiság negligálására irányuló - kollektív önrendelkezési jogot takar. A szerződés kifejezetten tiltotta a mandátumterület idegen hatalomnak való átengedését is (5. cikkely).

\subsection{Palesztina felosztása már megtörtént}

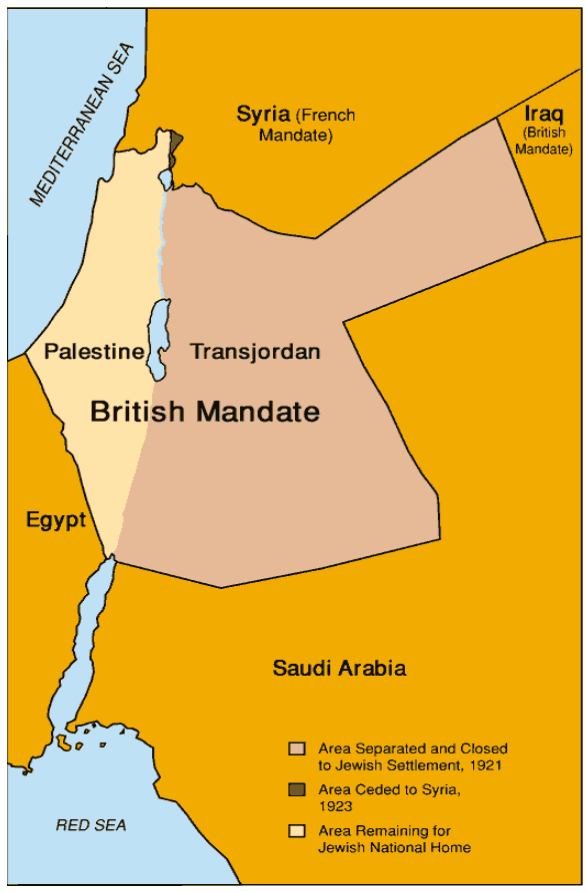

A palesztinai brit népszövetségi mandátumszerződés tartalmának kialakításánál közrejátszott az a tény is, hogy egyidejúleg az arabok önállóságának megalapozásához bőséges területet biztosítottak másutt, a Közel-Kelet többi, ugyancsak a török uralom alól felszabadított régiójában, Libanonban, Szíriában és Mezopotámiában. Nagy-Britannia ezt az araboknak juttatott területet még tovább bővítette azzal is, hogy a palesztinai mandátumterületet a Jordán folyó vonala mentén kettéosztotta, röviddel a mandátumszerződés létrejötte után, 1922 őszén. A folyótól keletre eső teljes (a mandátum nagyobbik, mintegy háromnegyed részét kitevő) területet kifejezetten az araboknak biztosították majdani - a későbbi Jordánia keretében megvalósult - önálló államiságuk alapjaként. A folyó és a Földközi-tenger közé eső teljes területet, Jeruzsálem városát sem kivonva innét, azonban a zsidó nemzeti otthon számára tartották fenn.

4. kép: A palesztinai brit mandátumi terület kettéosztása $(1922)^{23}$

${ }^{23}$ A kép forrása: https://www.jewishvirtuallibrary.org/map-of-the-british-mandate-1921-1923 (๔ AICE). 
Ennek az intézkedésnek a szerzôdés - kifejezetten e célból, előre beiktatott - 25. cikkelye ágyazott meg, miszerint: a „Jordán és Palesztina véglegesen megállapitott keleti határa köžé esö földsávon (a szerző megjegyzése: tehát csak ott), a Népszövetségi Tanács jóváhagyása mellett, a Megbizott Hatalom rendelkezzéé azzal a joggal, hogy elhalassza, vagy visszatartsa azoknak a mandátumi rendelkezéseknek a végrehajtását, amelyeket a fennálló helyi viszonyokkal összeegyeztethetetlennek itél (...)”.

Így „Palesztina” politikai és jogi felosztása az arab és zsidó felek között már 1922-ben megtörtént. Ennek alapján született meg a palesztinai mandátumból 1946-ban először az ottani arab állam, a Transzjordániai Hasemita Királyság, a mai Jordánia. ${ }^{24}$ A Jordán folyótól nyugatra eső teljes mandátumterület azonban - a Népszövetség által elismert és garantált jogcím alapján - vitán felül a zsidó állam számára volt fenntartva.

\section{Az izraeli-arab területi kérdések nemzetközi jogi megítélése 1947 után}

\subsection{A mandátumi jogosultságok továbbélése}

Amikor 1945-ben a Népszövetség helyére az ENSz lépett, a Népszövetség megszűnése nem jelentette a korábbi mandátumszerződésekből eredő jogok és kötelezettségek megszűnését. Ezt igazolja egyrészt, hogy maga az ENSZ Közgyúlése az 1947. november 29-i határozatában ${ }^{25}$ maga is foglalkozott a palesztinai brit mandátum további sorsával, azaz létezőnek tekintette azt. Másrészt az ENSZ Nemzetközi Bírósága is megerősítette a (korábban német gyarmati, majd dél-afrikai mandátumi jogállású) Délnyugat-Afrika ügyében hozott határozataiban, hogy a népszövetségi mandátumból eredő jogok és kötelezettségek a Népszövetség megszűnése után is tovább éltek. ${ }^{26}$

Az ENSZ maga is gyámsági rendszert alakított ki a még önállóságukat el nem nyert korábbi gyarmati területek kezelésére. Alapokmányának a nemzetközi gyámsági rendszerről szóló XII. fejezete 80. cikke szerint mindaddig, amíg nem jönnek létre az egyes területeket (köztük a mandátum alatt álló területeket) a gyámsági rendszer alá helyező külön megállapodások, „ennek a fejezetnek egyetlen rendelkęését sem lehet úgy értelmezni, hogy bármely módon akár közvetlenül, akár közvetve megváltoztatja valamely állam, vagy valamely nép (!) jogát, vagy valamely olyan hatályban levö nemzetközi okmány rendelkezéseit, amelyben a sžervezet tagjai részeseke lehetnek.". Mivel Palesztina területére nem kötöttek újabb gyámsági megállapodást, ott a korábbi, a népszövetségi mandátumból eredő jogok és kötelességek - így a zsidó nemzeti otthon létrehozása a folyótól a tengerig terjedő területen maradtak hatályban mindaddig, amíg ezeket újabb érvényes nemzetközi rendelkezés nem írja felül. A zsidó nemzeti otthon részére kijelölt „folyó és a tenger” közti terület további felosztására így csak a mandátumi rendelkezéseknek (jogosultságoknak) nemzetközileg joghatályos - a feljogosított

\footnotetext{
${ }^{24}$ A brit kormány már 1921-ben elkötelezte magát egy majdani arab állam kialkítására a palesztinai mandátumnak a transzjordániai részén.

25 UN General Assembly Resolution 181 (II.) Future government of Palestine, November 29, 1947 https://unispal.un.org/DPA/DPR/unispal.nsf/0/7F0AF2BD897689B785256C330061D25, magyarul lásd Dokumentumok a Közel-Kelet XX. századi történetéhez 253-266.

${ }^{26}$ South-West Africa Cases; Advisory Opinion Concerning the International Status, International Court of Justice (ICJJ), 11 July 1950, https://www.refworld.org/cases,ICJ,4028e9d44.html; International Court of Justice on South West Africa Cases (Judgement of 21-XII-62), https://www.icj-cij.org/files/case-related/46/046-19621221-JUD-0100-BI.pdf; Advisory Opinion on the Legal Consequences for States of the Continued Presence of South Africa in Namibia (South West Africa) notwithstanding Security Council resolution 276 (1970), https://www.icjcij.org/files/case-related/53/053-19710621-ADV-01-00-BI.pdf.
} 
fél hozzájárulását bíró - felülírásával volt és van lehetôség. Minden ezzel ellentétes megoldás negligálja ugyanis a zsidó népnek a Népszövetség, mint a korabeli nemzetközi világszervezet (továbbá rajta kívül is az Amerikai Egyesült Államok) által elismert történelmi jogát, és tagadja a zsidó államiság nemzetközi jogi alapját.

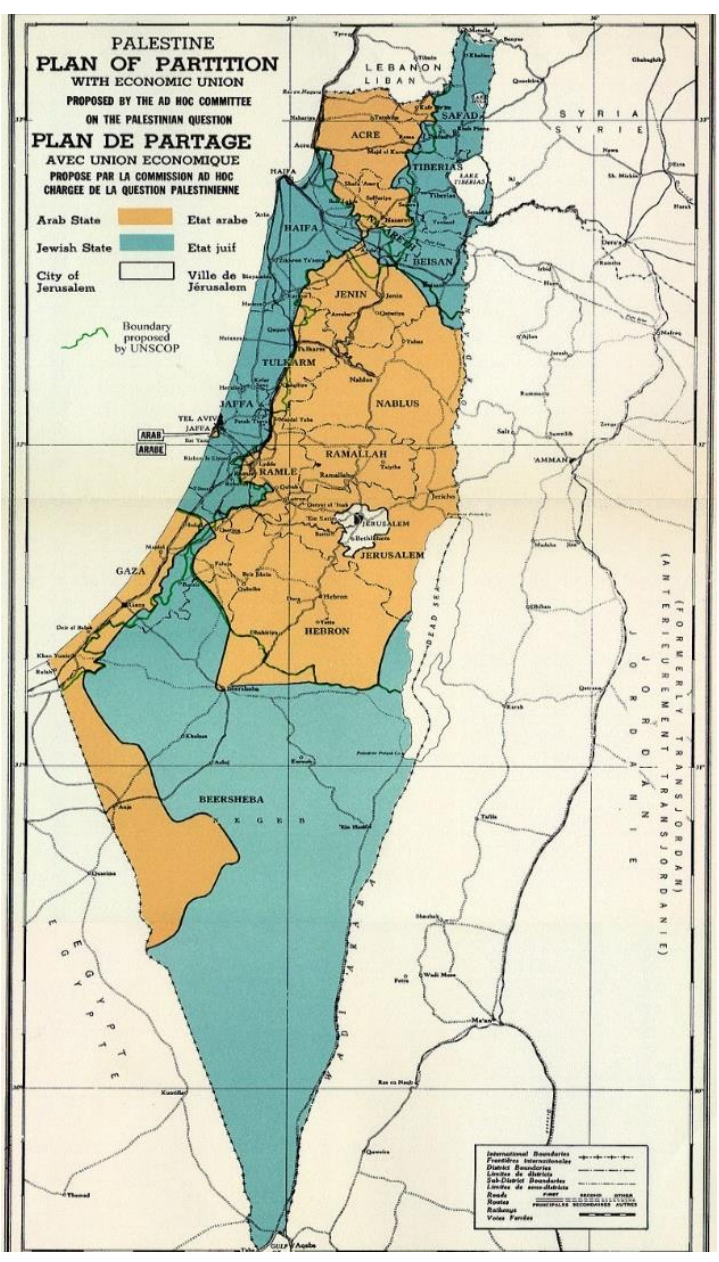

5. kép: Az ENSz felosztási terve, 194727

Ilyen - a mandátumi jogosultságokat felülíró - rendezés lehetett volna például az ENSZ Közgyúlés 1947. november 29-i 181. (II) számú felosztási határozata, ha azt nem pusztán Izrael, hanem az arab oldal is elfogadta volna, hiszen a határozat a felosztást és annak területi határait illetően csak az összes érintett egyetértésével válhatott volna joghatályossá. Az ENSZ határozat a folyótól a tengerig terjedő terület kettéosztását javasolta egy zsidó és egy arab állam céljára, Jeruzsálemet pedig nemzetközi igazgatás alá kívánta vonni (corpus separatum). Azonban az arab oldal ('́gy Izrael szomszédjai és maga a palesztinai arab vezetés is) elutasította az ENSZ határozatot, sôt (sikertelen) háborút indított a folyótól a tengerig terjedő teljes terület elfoglalására (első arab-izraeli háború). Ezért ez a területfelosztás és annak javasolt határai nem léptek hatályba, és így - az újabb hatályos nemzetközi rendezés híján - jogilag fennmaradt a korábbi, 1922. évi mandátumi területfelosztás, hiszen ezek után Izrael nem mondott le a kérdéses részeket illető területi felségjogáról, erre irányuló joghatályos nemzetközi döntés, megállapodás sem született.

Mivel az ENSZ nem nemzetek fölötti, hanem nemzetközi szervezet, ezért Közgyűlésének és Biztonsági Tanácsának határozatai jogilag nem kötelezőek automatikusan, még akkor sem, ha azokat határozatnak nevezik. ${ }^{28}$ Kötelezővé az érintettek elfogadása által válnak. Kivétel ez alól, amikor már fennálló nemzetközi szokásjogot rögzítenek határozatban ${ }^{29}$ vagy a Biztonsági Tanács az Alapokmány VII. fejezete szerinti eljárásban („eljárás a béke veszélyeztetése, a béke megszegése és támadó

\footnotetext{
${ }^{27}$ A kép forrása: https://en.wikipedia.org/wiki/United_Nations_Partition_Plan_for_Palestine\#/media/ File:UN_Palestine_Partition_Versions_1947.jpg.

${ }^{28}$ Lásd hozzá még KovÁcs, Nemzetközi közjog 1074; KENDE - NAGY - SONNEVEND - VALKI, Nemzetközi jog 1477, 1492-1493, 1796.

${ }^{29}$ Lásd például az agresszió fogalmát definiáló 1974-ben hozott 3314 (XXIX). sz. ENSZ közgyűlési határozatot. Itt azonban nem a határozat a kötelezettség forrása, hanem maga a már korábban kialakult szokásjog, aminek, illetve az általános gyakorlattal kapcsolatos opinio juris-nak pusztán bizonyítéka a határozat. Lásd hozzá KovÁCs, Nemzetközi kÖzjog 343; KENDE - NAGY - SONNEVEND - VALKI, Nemzetközi jog 1882.
} 
cselekmények esetében’) hoz kifejezetten kötelező rendelkezéseket, kényszerintézkedéseket. ${ }^{30} \mathrm{Ez}$ történt például a volt Jugoszlávia területén, továbbá a Ruandában elkövetett, a nemzetközi humanitárius jogot súlyosan sértő cselekményekért felelős személyek megbüntetését szolgáló nemzetközi törvényszékek felállítása tárgyában (1993 és 1994), a Kuvaittal szembeni agresszió okán Irak elleni fegyveres katonai fellépésre való felhatalmazást adó (1990), vagy az iráni atomprogramot szankcionáló határozataiban. Az ENSZ eddigi arab-izraeli területi vonatkozású határozatai azonban nem többek politikai ajánlásoknál, melyek - bár a politikai mozgásteret jelentősen befolyásolják az érintettek általi elfogadás híján mégsem bírnak nemzetközi jogi relevanciával. Ilyenek többek között a Ciszjordániát (Júdea-Szamariát), Kelet Jeruzsálemet, Gázai övezetet „megszállt palesztin területeknek" minősítő, a Jeruzsálem egységes izraeli fôvárosként kezelésének és a Júdea-Szamaria területén létesülő zsidó települések létrejöttének ,jogellenességét”, továbbá a palesztin államiság, illetve a „kétállamos megoldás” célkitűzését hangoztató közgyűlési és biztonsági tanácsi „határozatok” sora. ${ }^{31}$ Ezek hangoztatása kelti azt a látszatot, mintha Izrael nemzetközi jogot sértene velük szemben. Attól azonban, hogy egy politikai testület sokszor kimond valamit a jövőt illető célként illetve elvárásként, az még nem válik nemzetközi joggá. A Nemzetközi Bíróságnak az izraeli-palesztin viszonylatban 2004-ben hozott „a megszállt palesz̨tin területen megvalósuló fal épitésének jogi követkęményei” elnevezésű állásfoglalása szintén nem kötelező érvényű, mivel nem ítélet, hanem úgynevezett tanácsadó vélemény. ${ }^{32}$

A Palesztina felosztására irányuló 1947. november 29-i ENSz közgyúlési határozatnak azonban mégis van egy fontos nemzetközi jogi hatása, ami betetôzte a modern zsidó állam megalakulását. Megerősítette, hogy a zsidó népnek joga van az önálló államra a történelmi hazájában, tehát a san remoi megállapodásban és a palesztinai brit mandátumszerződésben megelőlegezett zsidó nemzeti otthon formája nem más, mint egy szuverén zsidó nemzetállam, még ha annak a határaira vonatkozó ENSz javaslat nem is vált hatályossá. Ennek alapján a brit mandátumi kormányzás megszűnt és ezzel egyidejűleg 1948. május 14-én (május 15-i hatállyal) kikiáltották a független, modernkori Izrael Államot, amire tekintettel annak újraalapítása jogilag visszafordíthatatlanná vált.

\subsection{Az estoppel és az uti possidetis a nemzetközi közjogban}

Az izraeli állam területi kiterjedése nemzetközi jogi szemszögből nézve nem maradt tisztázatlan a felosztási javaslat arab elutasítása ellenére sem. Ez egyrészt - az érvényes felülírásuk híján fennmaradt - mandátumi jogosítványokkal magyarázható, másrészt Izrael jogcímét a teljes, korábban kijelölt, a „folyótól a tengerig” terjedő területre ezen felül két nemzetközi jogi jogelv, az estoppel-doktrina és a római jogi eredetű uti possidetis juris is biztosították.

\footnotetext{
${ }^{30}$ Kivételesen túlmutat ezen a Délnyugat-Afrika (Namíbia) fölötti mandátumot Dél-Afrikától megvonó 264 (1969) sz. határozat, amit viszont éppen az ENSz felügyelete alatti joghatályos kötelemből, a nemzetközi megbízásból eredő kötelezettségeknek a megbízott általi sorozatos megszegése indokolt.

${ }^{31}$ Lásd többek között az ENSz Biztonsági Tanácsának 252 (1968), 446 (1979), 465 (1980), 478 (1980), 799 (1992) és 2334 (2016) számú határozatait, továbbá a Közgyűlés 2253 és 2254 (1967), 3236 (1974), 66/17 (2012), 66/18 (2012), 67/19 (2012), 72/15 (2017) és 10/19 (2017). számú határozatait is.

32 A vélemény kritikáját lásd VALKI, A fal, Hágából nézve, http://www.grotius.hu/doc/pub/FZHCJH/2013-0627_valki_laszlo_a-fal-hagabol-nezve.pdf.
} 
Az estoppel elve $e^{33}$ a jogviszonyok kiszámíthatósága érdekében gátolja a feleket abban, hogy megtagadják, vagy ellentmondjanak annak, amit korábban mások jogosultságaként, eljárásaként, vagy jogszerűen fennálló helyzetként, illetve saját kötelezettségként akár egyoldalúan is kinyilvánítottak, elismertek, elfogadtak ezt kifejező, vagy erre utaló aktus által. Összefüggésben áll a jóhiszemúen szerzett és gyakorolt jogok védelmével, amibe beletartoznak az ilyen aktusokra alapozott jogok és helyzetek is. Ekként ezt az elvet mára már a szerződések jogáról szóló 1969-es bécsi egyezmény ${ }^{34}$ irásban is rögzíti áttételesen és részlegesen. Az egyezmény kimondta, hogy egy szerződés megszűnése nem érinti „a részes feleknek aẓt a jogát, kötelezettségét, vagy jogi helyzetét, amely a szerzớdés végrehajtása során, annak megszünése elött keletkezett" - kivéve, ha maga a szerződés másként nem rendelkezik. Ráadásul, mint korábban bemutattuk, a mandátumszerződésből eredő jogok és kötelezettségek kimondottan nem szűntek meg azzal, hogy a Népszövetség helyét az ENSZ váltotta fel. Önmagában tehát már az estoppel elve is alátámasztja, hogy különösen egy egyoldalú aktustól többől, nevezetesen szerződésből eredő jogokon és kötelezettségeken nem lehet keresztül lépni azok joghatályos módosítása nélkül.

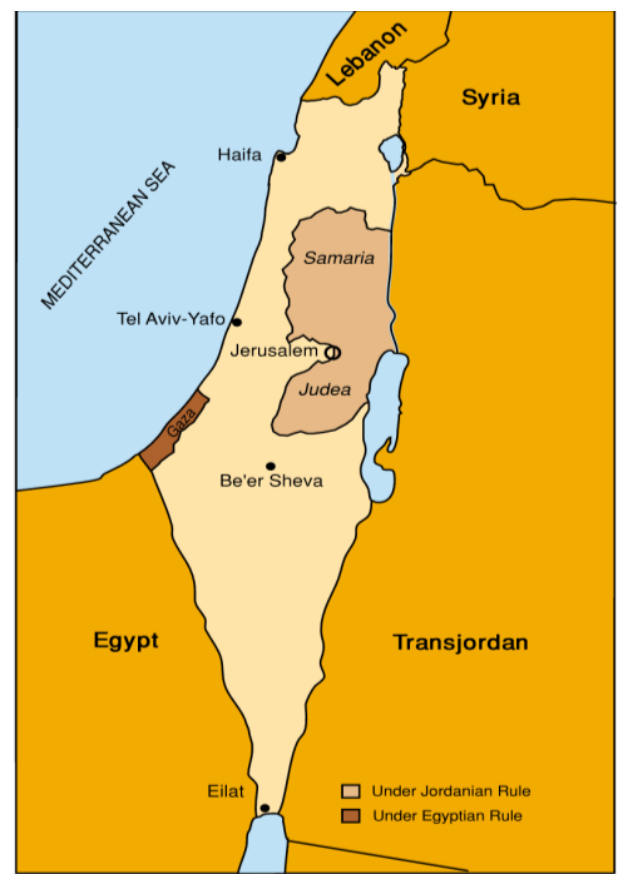

Az uti possidetis elvet az önálló állammá váló volt gyarmatok határainak megrajzolásánál emelték nemzetközi jogi rangra. Az ,ahogyan birtokoltátok”- értelem ebben az esetben azt jelenti, hogy az érintettek eltérő megállapodása hiányában a korábbi gyarmati, illetve közigazgatási határaik váltak az önálló államok határaivá változtatás nélkül. Ez az elv köszönt vissza a volt Szovjetunió és a volt Jugoszlávia utódállamainak határ-megállapításánál is, függetlenül attól, hogy általa egyes esetekben jelentôs létszámban rekedtek kisebbségben az önállóvá vált államokat alkotó nemzetek tagjai a szomszédos államok területén. ${ }^{35}$ Izraeli viszonylatban az uti possidetis a mandátumi határok államhatárrá fejlesztését támasztotta alá.

6. kép: Az első háború utáni fegyverszüneti vonalak, $1949^{36}$

\footnotetext{
33 A ,civilizált nemzetek által elismert általános jogelvként” nemzetközi rangot élvező angolszász estoppel elvben több jogelv vegyül, így a jóhiszemű eljárás, pacta sunt servanda és a venire contra factum proprium nulli conceditur. Jelen esetben azt fejezi ki, hogy a zsidó nemzeti otthon létrehozatalára és annak területére tett elköteleződést, ha annak kialakítása elkezdődött, nem lehet utólag megváltoztatni vagy visszavonni (még az egyoldalúakat sem). Ennek tükrében eleve jogsértésnek, illetve kötelezettségszegésnek minősültek azok az 1930-as évek második felétől tett brit intézkedések is, amelyek eltértek a mandátum eredeti területi célkitűzéseitől. Az estoppel nemzetközi jogi értelmezéséhez lásd VOYIAKIS, Estoppel; COTTIER - MÜLLER, Estoppel. Lásd az Állandó Nemzetközi Bíróság 1933-ban hozott döntését a dán-norvég területi vitát képező Kelet-Grönland ügyben, aminek alapját egy 1919-es norvég külügyminiszteri kijelentés (az úgynevezett Ihlen-deklaráció) képezte, amire Dánia joggal alapozott területi igényt: http://www.worldcourts.com/pcij/eng/decisions/1933.04.05_greenland.htm.

${ }^{34}$ Magyarországon kihirdette az 1987. évi 12. tvr. Lásd az egyezmény 70. cikk 1/b. pontját.

${ }_{35} \mathrm{Az}$ uti possidetis-elv alkalmazásáról lásd VALKI, Az államelismerés, mint jogi fegyver 121-142.

${ }^{36}$ A kép forrása: https://www.jewishvirtuallibrary.org/armistice-lines-map-1949 (๔ AICE).
} 
Nem véletlen, hogy az 1948-as első arab izraeli háború után senki sem bélyegezte nemzetközi jogba ütközőnek azt a tényt, hogy Izrael az ENSZ felosztási javaslatához képest nagyobb területen kezdte meg a tényleges állami múködését, hiszen a szóban forgó területek mind a korábbi mandátumi határokon belül esnek. Ebben a háborúban azonban Transzjordánia elfoglalta Ciszjordániát (Júdea-Szamariát) és Kelet-Jeruzsálemet, Egyiptom pedig a Gázai övezetet. Nekik azonban semmilyen jogcímük nem volt rá, hogy bármiféle - a Jordán folyó vonalától nyugatra eső - egykori mandátumterületet birtokoljanak: ezeket a területeket a mandátumszerződés a zsidó nemzeti otthon számára, az ENSZ felosztási javaslata pedig önálló arab állam számára jelölte ki.

Transzjordánia ráadásul 1950-ben annektálta is területfoglalásait és egyidejűleg államának elnevezését Jordániára (Jordánia Hasemita Királyság) változtatta, hiszen azzal, hogy a Jordán folyó mindkét oldalán berendezkedett, megszűnt az értelme a folyón túlra utaló „transz” jelzőnek az állam elnevezésében. Az annexiót (a Kelet-Jeruzsálemre utaló rész kivételével) mindössze NagyBritannia és Pakisztán ismerték el. ${ }^{37}$ E területeket az említett államok egészen az 1967-es arab-izraeli háborúig megszállásuk alatt tartották. Annak ellenére sem hoztak létre önálló arab államot ott, hogy erre - az ENSZ felosztási javaslatának egyfajta utólagos elfogadásával - akkor még elvileg hivatkozhattak volna. Ezzel maga Transzjordánia és Egyiptom és a jelenlétüket támogató helyi arab vezetők is világossá tették, hogy nem gondolkodtak önálló palesztinai arab államban.

Jelentőséggel bír nemzetközi jogilag az a tény is, hogy az első háború után Izrael szomszédjai nem voltak hajlandóak békeszerződést kötni a zsidó állammal, így ezzel is lemondtak róla, hogy a mandátumi határvonalaktól eltérô nemzetközi jogi államhatárokban állapodjanak meg, holott Izrael készen állt erre államának elismerése és a béke garantálása fejében. Ehelyett csak fegyverszüneti egyezmények születtek, amelyek mindössze a háború végeztével kialakult tűzszüneti vonalakat avatták fegyverszüneti vonalakká (green lines), leszögezve, hogy ezek nem minősülnek végleges határoknak. ${ }^{38}$ Ezek a megállapodások Izrael és a szomszédos arab államok között köttettek, a palesztinai arabokra nem vonatkoztak, így rájuk nézve nem jelentettek a legkisebb mértékű elköteleződést sem.

\subsection{A hatnapos háború és következményei}

Az eddig ismertetett történeti és nemzetközi jogi tények messzemenően meghatározzák az 1967-es hatnapos arab-izraeli háború nyomán előállt helyzet jogi értékelését is. Ennek - az Izrael szomszédjai által kiprovokált - háborúnak az eredményeként került izraeli kézbe az addig az első háború óta Jordánia által megszállt Ciszjordánia (Júdea-Szamaria) és Kelet-Jeruzsálem, továbbá az Egyiptom által megszállt Gázai övezet. Izrael ezeken felül elfoglalta még Egyiptomtól a Sínai félszigetet, Szíriától pedig a Golán fennsíkot. Az 1967-es háborúban Izrael ellenőrzése alá került területek státusza és az onnét való izraeli kivonulás mértékének kérdése az óta is a közel-keleti rendezés legvitatottabb, központi témái közé tartozik.

\footnotetext{
${ }^{37}$ ABU JABER, Transjordan, the Hashimite Kingdom and the Palestine war, passim.

${ }^{38}$ Egyiptomi-izraeli fegyverszüneti egyezmény V. cikkely 2. pontja, izraeli-jordániai egyezmény VI. cikkely 9. pontja. Ráadásul az Arab Liga Tanácsa 1950-ben kizárással fenyegette azon tagjait, akik különbéke szerződést, vagy bármely más politikai, katonai, vagy gazdasági megállapodást kötnének Izraellel. Lásd hozzá KÁDÁR, Az 1949-es izraelitranszjordániai fegyverszüneti tárgyalások dokumentumai 97.
} 


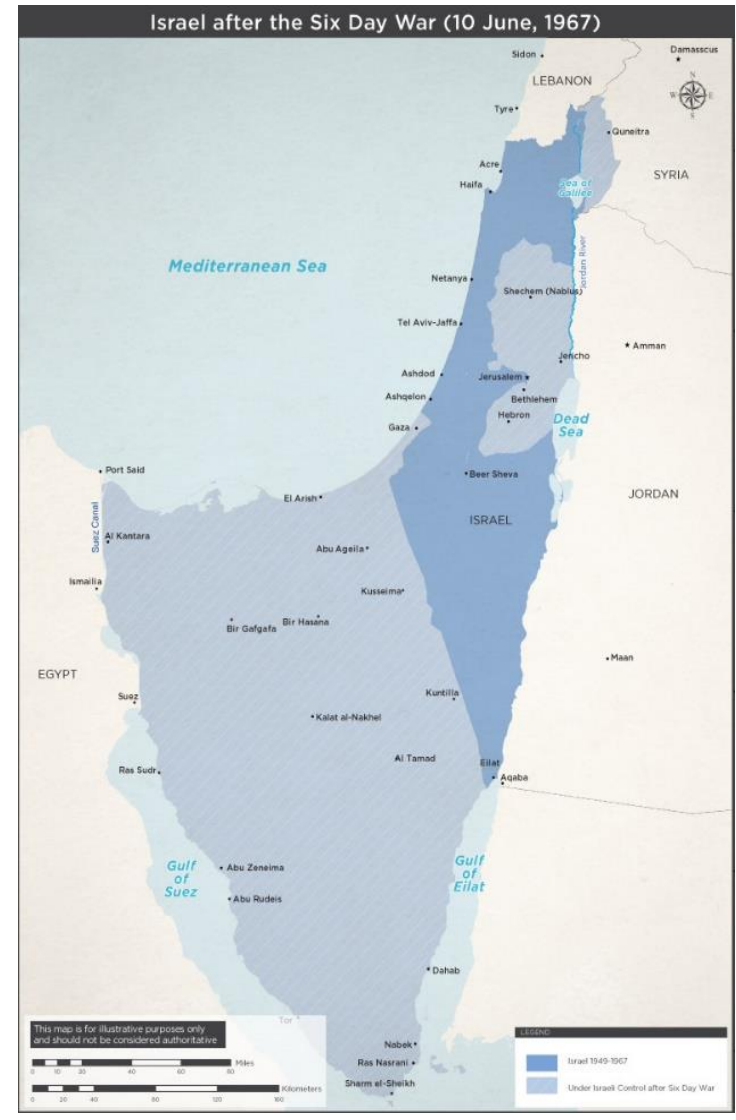

7. kép: A hatnapos háború előtti (sötétkék) és utáni (világoskék) izraeli területek, 196739
Akik Ciszjordániát (Júdea-Szamaria), a Gázai övezetet és Kelet-Jeruzsálemet illetően izraeli megszállásról beszélnek, abból indulnak ki, hogy Izrael fegyveres agresszió (jogellenes erőszak) révén jutott ezeknek a területeknek a birtokába, és ezek a területek tőle idegen területek, azaz más államokéi, vagy legalább is a „palesztin népet” illető, annak önrendelkezése alá eső területek. Mindebből következtetnek arra, hogy azokról Izraelnek, mint „megszálló hatalomnak” maradéktalanul ki kell vonulnia az „1967-es határok” (értsd a háború előtti, nevezetesen az 1949-es fegyverszüneti vonalak) mögé, és ezeken a területeken, mint „megszállt területeken" jogellenesnek számít zsidó települések létesítése, továbbá a nemzetközi jogba ütközik ezeknek a területeknek, vagy akár csak egy részüknek az „annektálása” és Jeruzsálemnek Izrael egységes fóvárosaként kezelése. Az említett kiindulópontok azonban nemzetközi jogi értelemben nem állnak meg, és ezért helytelen a belölük levont következtetés is.

Az erőszak alkalmazásának és az agressziónak a tilalma valóban a nemzetközi jog kógens szabályai közé tartoznak. Az ENSZ Alapokmánya ${ }^{40}$ kimondja: „A szervezet tagjainak nemzetközi érintkerzéseik során más Alllam területi épsége, vagy politikai függetlensége ellen irányuló, vagy az. Egyesült Nemzetek céljaival össze nem férö bármely más módon nyilvánuló eröszakekal való fenyegetéstöl vagy eröszak alkalmazásától tartózkodniuk kell.” (2. cikk 4. bek.) Az erôszak minősített változatának, az agressziónak a tényállását, mint már korábban is érvényes nemzetközi szokásjogot - mintegy annak bizonyítékaként - 1974ben tételesen írásba foglalta az agresszió meghatározásáról szóló 3314 (XXIX). sz. ENsz közgyűlési határozat, ${ }^{41}$ mely szerint: „Az agresszió fegyveres erö alkalmazása egy állam által más állam szuverenitása, terïleti integritása, vagy politikai függetlensége ellen, illetve az. ENSZ Alapokmányával össze nem férö bármely más módon" (1. cikk). ${ }^{42}$ Ténykérdés azonban, hogy a kérdéses területek nem izraeli fegyveres agresszió révén, hanem önvédelmi háborúban kerültek izraeli ellenőrzés alá. Az ENSZ Alapokmány 51. cikke ugyanis a tagállamokat az ellenük irányuló fegyveres támadás esetén feljogosítja az „önvédelem

\footnotetext{
39 A kép forrása: https://www.jewishvirtuallibrary.org/map-of-the-cease-fire-lines-after-the-six-day-war-june-1967 (C AICE).

${ }^{40}$ Magyar szövegét lásd az Egyesült Nemzetek Alapokmányának törvénybe iktatásáról szóló 1956. évi I. törvényben.

${ }^{41}$ UN General Assembly Resolution 3314 (XXIX), https://undocs.org/en/A/RES/3314(XXIX).

42 A határozat az agresszió definícióját követően felsorolja annak esetköreit is. Jogerejét bizonyítja, hogy Nemzetközi Büntetőbíróság statútumába is szó szerint így került be, lásd. 8. cikkely - Crime of aggression, lásd https://www.icccpi.int/resource-library/documents/rs-eng.pdf.
} 
természetes jogának” gyakorlására „mindaddig, amíg a Biz̧tonsági Tanács a nemzetközi béke és biz̧tonság fenntartására szülkséges rendsz̧abályokat meg nem tette”.

Egyiptom az Akabai-öböl 1967 májusának végén megvalósított fegyveres blokádjával elkövette az ENSZ tagállam Izrael elleni agressziót. Más állam kikötőinek, vagy partvidékének fegyveres blokádja ugyanis a nemzetközi szokásjog alapján kimerítette a támadó cselekmény fogalmát. ${ }^{43} \mathrm{Ez}$ a katonai lépés együtt járt a Sínai-félszigeten és a Gázai övezetben állomásozó ENSz békefenntartó erôk egyiptomi kérésre történt evakuálásával, majd Izrael öt arab ország (köztük Jordánia) hadereje részéről történő körbezárásával.

Mindezt a zsidó állam „tengerbe söprését” hirdető háborús propaganda övezte. Ez nem hagyott kétséget a fegyveres blokád és a katonai körülzárás céljáról és egyben az 1949-es fegyverszüneti egyezmények teljes megsértését is jelentette. Az ENSZ semmilyen hathatós intézkedést nem tett a biztonság fenntartására, sőt a békefenntartók egyoldalú visszarendelésével maga is döntően hozzájárult a feszültség eszkalálódásához. Mindezek megalapozták az izraeli önvédelmi jogot. Ténykérdés az is, hogy az ENSz égisze alatt a mai napig sem kerültek kidolgozásra a térséget illetően a nemzetközi béke és biztonság fenntartására alkalmas biztonsági garanciák. A garanciák hiánya pedig a területi épségének és biztonságának megvédése okán önmagában is érvényes jogcímet ad Izraelnek a Golán fennsík és a Jordán folyó nyugati völgyének birtoklására e területek hadászati, stratégiai jelentősége miatt.

Ciszjordániára (Júdea-Szamariára), Kelet-Jeruzsálemre és a Gázai övezetre ezen felül eleve fennállnak Izraelnek a mandátumszerződésből eredő korábbiakban említett területi jogosítványai is. Ezeken a földterületeken ezért Izrael nem tekinthetô megszálló hatalomnak, illetve ezek a területek nem minősíthetők Izrael által megszállt területeknek. Izrael ugyanis nem tőle idegen, hanem saját, a zsidó nemzeti otthon részére rendelt területet vett birtokba, töretlenül fennálló érvényes jogcíme alapján. Olyan területeket, melyeket Jordánia és Egyiptom fegyveres agresszió révén, jogellenesen foglaltak el az első arab-izraeli háborúban, hiszen részükre semmilyen korábbi nemzetközi rendezés (de még terv sem) ígért, illetve ismert el semmiféle jogcímet ott. Az ex injuria jus non oritur (jogellenesség nem teremt jogot) elv kizárta azt, hogy ôk ott bármilyen igényt tarthassanak fenn. ${ }^{44}$ Ezen a tényen nem változtat az sem, hogy az 1967-es háború után biztonsági okokból és bízva a szomszédokkal való béketárgyalások előmozdításában, ezekre a területekre (Kelet-Jeruzsálem kivételével) Izrael nem terjesztette ki saját törvényeinek az alkalmazását, hanem önkéntes elhatározása alapján katonai kormányzás és a nemzetközi (genfi) humanitárius jog alkalmazása mellett döntött annak ellenére, hogy erre a területi felségjogát alátámasztó érvényes jogcím birtokában nem lett volna köteles. Ez nem okozott „szuverenitási vákuumot”, hiszen ténylegesen a területeket Izrael kormányozta, mégpedig olyan konstrukcióban, amiről önmaga döntött szabadon.

Ami meg a ciszjordániai és a gázai arab lakosság (palesztinok) viszonylatát illeti, ők sem Izrael újraalakulása előtt, sem utána nem képeztek önálló államot és a nemzetközi jogi kritériumok

\footnotetext{
43 Amint ezt, mint addig is létező szokásjogot az említett 3314 (XXIX). számú közgyúlési határozat utóbb maga is rögzítette: „tekintet nélkül arra, hogy történt-e hadüzenet, vagy sem”, agressziónak minősül az is „ha egy állam kikötöit, vagy partvidékét más állam fegyveres eröi blokád alá veszike” (3. cikk c/ pont).

${ }^{44}$ Lásd GOLD, From „occupied territories” to „disputed territories”, passim.
} 
teljesítése híján a jelen cikk írása idején sem rendelkeznek ilyennel, ${ }^{45}$ annak ellenére sem, hogy az utóbbi években már erre hivatkoznak. Valójában a palesztin államiságra a jövőben megvalósítandó célként tekintenek mind ők, mind az úgynevezett „kétállamos” megoldást forszírozó nemzetközi megnyilatkozások. Palesztin államiság hiányában pedig palesztin viszonylatban a nemzetközi jog alapján eleve nem lehet megalapozottan „megszállásról” beszélni. A vonatkozó nemzetközi jogi normák (mind az úgynevezett hágai és genfi háborús szabályozás) értelmében a „megszállás” ugyanis más államok területe vonatkozásában merül fel. ${ }^{46}$

Megszállás és idegen hivatalos állami terület híján nemzetközi jogilag nem jelent annexiót (más állam területének elcsatolását, avagy bekebelezését) ${ }^{47}$ akár a teljes izraeli joghatóság kiterjesztése sem Ciszjordániára, vagy akár a Gázai övezetre, hanem ez a mandátumi jogok és az uti possidetis juris, valamint az estoppel elvei alapján a folyótól a tengerig terjedő egész területre irányuló szuverenitás kiteljesítését jelenti. Így Izraelnek, mint a kérdéses területek fölött érvényes nemzetközi jogcímmel rendelkező államnak szuverén joga lett volna (és a cikk megírása idején is ez van rá) államának 1948-as megalapítása óta a teljes joghatóságát kiterjeszteni Ciszjordániára, mint ahogyan ezt Kelet-Jeruzsálem vonatkozásában korábban már megtette. Az a tény, hogy ezzel a jogával eddig nem élt, hanem az igazgatás más formáját alkalmazta, kifejezetten Izrael szuverén hatáskörébe tartozó kérdés, joglemondást nem jelent.

A ciszjordániai (júdea-szamariai) zsidó települések létrejöttének jogalapját is az érvényben maradt mandátumi jogosultság képezi ${ }^{48}$, ami csak akkor válna jogellenessé, ha az a korábban ott lévô arab városok, falvak felszámolását, az arab lakosság kitelepítését eredményezné. Ilyen azonban nem történik, a zsidó „telepek” a történelem folyamán elhagyott, lakatlan területeken jöttek/jönnek létre.

Jeruzsálem városa nincsen külön nevesítve a mandátumszerződésben. Csak a szent helyek és vallási épületek fenntartására, megőrzésére, szabad látogatásukra és az istentiszteletek szabad megtartására irányuló általános előírások szerepelnek benne (13. cikkely), de nincsen utalás arra, hogy a várost ne kellene a zsidó nemzeti otthon részének tekinteni. Ez logikusan következik abból, hogy a mandátum deklarált célja a zsidó nemzeti otthon helyreállítása volt Palesztinában a föld és a nép közötti történelmi kapcsolat elismerése okán. A történelem során pedig Jeruzsálem sosem volt egyetlen muszlim, illetve arab ország fővárosa sem, ellentétben a korabeli Izraellel.

\footnotetext{
45 Meghatározott terület, állandó lakosság, múködőképes kormány, képesség más államokkal való kapcsolat fenntartására. Montevideo Convention on the Rights and Duties of States (1933), 1. cikk. https://www.jus.uio.no/english/services/library/treaties/01/1-02/rights-duties-states.xml.

Palesztina esetében a meghatározott terület és az önálló, működőképes kormány jelenleg is hiányzik. A mostani palesztin autonómia „területe” már csak annak övezeti felosztása és a „C” övezetben fenntartott izraeli igazgatási jogok miatt sem vehetô alapul.

${ }^{46}$ Lásd az 1907. évi IV. hágai egyezmény mellékletének „A katonai hatalomról az ellenséges állam területén” című III. részét (1913. évi XLIII. törvény az első két nemzetközi békeértekezleten megállapított több egyezmény és nyilatkozat beczikkelyezése tárgyában), továbbá az 1949-es IV. genfi egyezménynek a „Megszállt terïletekre” vonatkozó III. részét, melynek több cikke is „megszállt állam/orsðág” kifejezést alkalmazva egyértelműsíti, hogy mit kell érteni a „megszállt” területen (például 51., 53. és 56. cikkek).

${ }^{47}$ „Annexation means the forcible acquisition of territory by one State at the expense of another State.", lásd HOFMANN, Annexation; KENDE - NAGY - SONNEVEND - VALKI, Nemzetközi jog 1891.

48 „Palesztina kormánya a más fajú lakosság jogainak és belyzetének biz̨tositása mellett, könnyítse meg a zsidó bevándorlást (...) segitse elö a zárt zsidó letelepedést a földön, ideértve a nem közcélokra felhasználható állami birtokokat és parlagon heveró földeket is.” A mandátumszerződés 6. cikkelyét lásd Dokumentumok a Közel-Kelet XX. századi történetéhez 101.
} 
Figyelemmel az - ellenkező megállapodás híján - a mandátumi közigazgatási határokra jogosító uti possidetis elvére is, a városra Izrael rendelkezett illetve rendelkezik a legerősebb jogcímmel. Az államok szuverén egyenlőségének elvéből (ENSZ Alapokmány 2. cikk 1. pont) is fakad, hogy egy állam maga választhassa meg a saját fővárosát.

\subsection{Az ENSZ BT 242. számú határozatának értelmezési kérdései}

Az 1967-es háború után, 1967. november 22-én született meg az ENSz Biztonsági Tanácsának nevezetes 242. számú határozata „a közel-keleti helyzetröl”, "9 ami az óta is rendszeres hivatkozási alap a rendezési kísérletek során. Bár erre is áll, hogy önmagában nem teremtett nemzetközi jogi kötelezettségeket, mégis igyekeznek a politikai vitákban rendszeresen ilyenként beállítani és ennek alapján követelni például Izrael visszavonulását az „1967-es határok” (értsd az 1949-es fegyverszüneti vonalak) mögé. Azonban a közhiedelemmel ellentétben ez a határozat eredetileg még politikai szándékként sem írta elő az 1967-es háborúban Izrael fennhatósága alá került összes területről való kivonulást.

A határozat nem bélyegezte agresszornak Izraelt (harca önvédelmi jellege eleve kizárta az ehhez szükséges egyetértést). Csak a háború útján történő területszerzés megengedhetetlenségét deklarálta a preambulumban, ami érthető is abból a szempontból, hogy Izrael szomszédjainak deklarált célja a zsidó államterület elfoglalása és az állam felszámolása volt, Izrael pedig a mandátumi területeket meghaladó részeket (például a Sínai-félszigetet) is ellenőrzése alá vont. A palesztinai arabok kapcsán a határozat mindössze „menekültproblémáról” (annak „igazságos rendezéséról”) ${ }^{50}$ szól, tehát javukra semmilyen közösségi jogot (pl. önrendelkezési jogot) nem alapoz meg, és nem is tekinti őket önálló, palesztin etnikumnak.

A határozat két alapelvet rögzített, amelyeken a Biztonsági Tanács szerint a térség „tartós és igazságos” békéjének kell alapulnia: (1) az izraeli fegyveres erők visszavonása a legutóbbi konfliktus során elfoglalt területekről, ${ }^{51}$ továbbá (2) a hadiállapot és mindennemű háborús módszerhez való folyamodás megszüntetése, a térség minden állama szuverenitásának, területi integritásának és politikai függetlenségének, valamint azon jogának elismerése, hogy biztonságos és elismert határaikon belül békében éljen, fenyegetéstől és erôszakos cselekményektől mentesen.

Az egyik alapelv szerint Izraelnek vissza kellene vonulnia az 1967-es háborúban elfoglalt területekről (de nem valamennyiről). ${ }^{52}$ A másik alapelv szerint el kell ismerni azt a jogát, hogy „,biztonságos és elismert” határokon belül békében éljen fenyegetéstől és erőszakos cselekményektől mentesen. A két alapelv nem sorrendiséget jelöl, hanem együtt értelmezendő: a csapatkivonásokat együtt kell kezelni a biztonságos határok garantálásával. Izrael visszavonulása a vele kötendő béke,

\footnotetext{
${ }^{49}$ Resolution 242 (1967), https://undocs.org/S/RES/242(1967), magyar nyelven lásd Dokumentumok a Közel-Kelet XX. századi történetéhez 404.

${ }^{50} \mathrm{Az}$,igazságos rendezés” mikéntjét a felek megállapodására bízta, tehát nem fogalmazott meg alanyi jogként úgynevezett visszatérési jogot.

51 Angolul „,Withdrawal of Israeli armed forces from territories occupied in the recent conflict”. A határozati javaslatot - az Egyesült Államokkal együttműködve - Nagy-Britannia munkálta ki és terjesztette angol nyelven a Biztonsági Tanács elé, így a vita és a határozathozatal alapja az angol nyelvű verzió volt. Értelmezési vita esetén ezért a munkanyelv, tehát az angol szöveg az irányadó.

52 A hivatalos angol szövegből nem véletlenül hiányzik az összes területre utaló határozott névelő, vagy az arra való kifejezett utalás: „withdrawal ... from [the (vagy: all)] territories occupied in the recent conflict”.
} 
csapatkivonásának, terület-kiürítésének mértéke pedig a biztonságos határok megrajzolásának függvénye.

Bár számos fordítás, köztük a magyar sem adja vissza, de a hivatalos (a határozott névelőt kifejezetten mellőző) angol nyelvű szövegből egyértelmű, hogy a határozat nem írja elő Izrael részére az 1967-es háborúban ellenőrzése alá vont összes területről való kivonulást, így a háború elôtti úgynevezett határokra való visszatérést. Csak biztonságos határokat eredményező mértékig kell visszavonulnia, melyekről tárgyalásokon kell megállapodni. Ilyen módon - nem pedig „,az 1967es határokhoz" való visszatéréssel - jött létre az egyiptomi-izraeli (1979) és a jordániai-izraeli (1994) békeszerződés. Az egyiptomi révén a Sínai-félszigetrôl az izraeli csapatok kivonultak, a Gázai övezet viszont Izrael ellenőrzése alatt maradt, azaz a korábbi mandátumi határvonal vált a két állam határává. Ugyancsak a korábbi mandátumi köztes határvonalat avatták a jordániai-izraeli államhatárrá jordániai-izraeli békeszerződésben azzal a kisebb korrekcióval, hogy Izrael átadott néhány kisebb földsávot a Holt tengertől délre, a Negev sivatag térségében. Jordánia ezzel visszavonhatatlanul lemondott az 1967-ben tőle visszafoglalt ciszjordániai (júdeai-szamariai) területekről. ${ }^{53}$

Látható tehát, hogy Izraelnek sem az egyiptomi, sem a jordániai határvonala nem az 1967es háború előtti fegyverszüneti vonal, hanem nagyvonalakban a korábbi, mandátumi határvonal. A palesztinai arabokkal pedig - mint már említettük - semmiféle ilyen korábbi, demarkációs vonalat meghúzó megállapodás nem került megkötésre, ezért nekik a Biztonsági Tanács 242. számú határozata még politikailag sem adott semmilyen hivatkozási alapot az „1967-es határokra”. Velük, jelesül a képviseletükben fellépő Palesztinai Felszabadítási Szervezettel Izrael csak később, az osloi egyezményekben állapodott meg, de nem palesztin állam, hanem területi autonómia létrehozásáról.

\subsection{Az Oslo I. és az Oslo II. megállapodások következményei}

Az Izrael és a PFSz között 1993-ban és 1995-ben Washingtonban aláírt (az úgynevezett Oslo I. és Oslo II.) megállapodások ${ }^{54}$ palesztin autonómiát létesítettek Ciszjordánia (Júdea-Szamaria) és a Gázai övezet területén. Ezek a megállapodások (amelyek közül az utóbbit a feleken kívül az UsA, Oroszország, Eu, Egyiptom, Jordánia és Norvégia tanúként írtak alá) maguk is Izrael egykoron neki kijelölt teljes mandátumterületre kiterjedő területi fennhatóságának a bizonyítékai, hiszen szerződő félként kifejezetten a saját, önkéntes hozzájárulása alapozta meg a palesztin autonómiát a kérdéses földterületeken. Azzal, hogy a palesztin oldal ezeket a megállapodásokat aláírta, gyakorlatilag maga is elismerte Izrael felségjogát a szóban forgó területek fölött. A palesztin autonómia által gyakorolt jogosítványok forrása ugyanis nem valamiféle eleve fönnálló állapotból

\footnotetext{
${ }^{53}$ Jordánia már ezt megelőzően, 1988-ban bejelentette, hogy lemond erről a területről, lásd „Hussz̨ein király bejelentése Jordániának a Nyugati Parttal (Ciszjordániával) fennálló közjogi kapcsolatai felmondásáról - Amman 1988. július 31.”, in: Dokumentumok a Közel-Kelet XX. századi történetéhez 540-544.

54 Az 1993-as Oslo I. megállapodás, amit eredeti elnevezése „Declaration of Principles on Interim Self-Government Arrangements" (https: //web.archive.org/web/ 20021115183950/http://knesset.gov.il/process/docs/oslo_eng.htm) okán „Elvi Nyilatkozatnak” is hívnak, a létrehozandó palesztin autonómia alapelveit fektette le. Ennek az elvein született meg 1995-ben az autonómiát részletesen szabályozó Oslo II. megállapodás (Interim Agreement on the West Bank and the Gaza Strip, https://www.jewishvirtuallibrary.org/interim-agreement-on-the-west-bank-and-the-gaza-strip-oslo-ii) és az I. számú mellékletet is (https://www.jewishvirtuallibrary.org/oslo-ii-annex-i). Magyarul lásd Dokumentumok a Közel-Kelet XX. századi történetéhez 711-727.
} 
eredő önálló palesztin rendelkezés az autonómia területe fölött, hanem az Izrael általi jogátruházás. Az 1995-ös megállapodásnak (Oslo II.) a „kormányzás átrubázásáról” szóló 1. fejezete I. részének 1. pontja kifejezetten rögzíti, hogy „Irrael a jelen Megállapodásban meghatározott jogositványokat és kötelezettségeket az izraeli katonai kormányzat és polgári közigazgatás kezéböl a Megállapodás értelmében a Palesz̨tin Tanácsra rubázza át. Az ilyen módon át nem rubázott jogosituányokat és kötelezettségeket Izrael továbbra is gyakorolni fogja”.

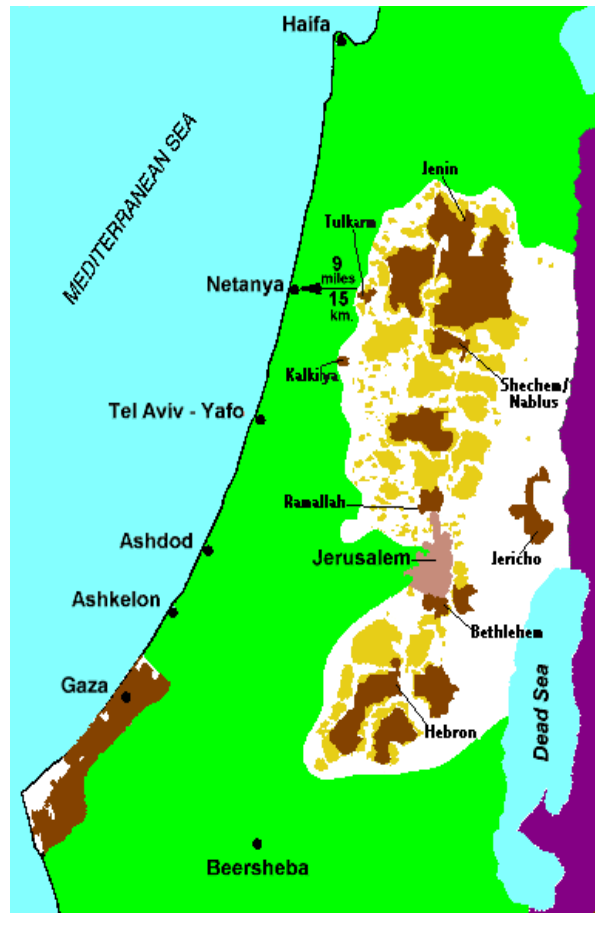

E területekre irányuló szuverenitásáról azonban Izrael egyáltalán nem mondott le, hiszen a külügy, hadügy és határvédelem területén, valamint az adott területen élő izraeli állampolgárokra vonatkozó igazságszolgáltatást, továbbá az úgynevezett „C” övezet igazgatását illetően kifejezetten fenntartotta az illetékességét. Csakis önmagán múlik, hogy kíván-e ezen a jövőben továbblépni, illetve az, hogy a fenntartott jogosítványait milyen jogi, igazgatási konstrukcióban kívánja gyakorolni. A közhiedelemmel ellentétben a megállapodás semmilyen kötelezettséget nem ír elő az ún. kétállamos megoldásra, azaz a palesztin területi autonómia szuverén palesztin állammá alakítására. Az önrendelkezési jog ugyanis nem egyenlő automatikusan az államalkotáshoz való joggal.

8. kép Az Oslo I-II. megállapodással létrejött állapot. Barna: „A” övezet teljes palesztin ellenőrzés alatt; sárga: „B” övezet palesztin közigazgatási, izraeli belbiztonsági hatáskör; fehér: „C” övezet teljes izraeli ellenőrzés alatt (tárgyalási téma); mályva: Jeruzsálem nem része a palesztin autonómiának, teljes izraeli joghatóság alatt (tárgyalási téma). ${ }^{55}$

Kétségtelen, hogy az osloi megállapodásban a felek kötelezettséget vállaltak arra, hogy az állandó státuszról tárgyaljanak, ez azonban semmilyen elkötelezettséget nem jelent palesztin állam létrehozására, hanem jelzi, hogy magának az autonómiának a múködését, hatásköreit illetően több nyitott kérdés is fennmaradt még. ${ }^{56}$ A megállapodás semmilyen konkrét végcélt nem ír elő: „, a jelen Megállapodás semelyik része sem vetíti elóre, vagy akadályozza az ... állandó státuszról szóló tárgyalások eredményeit." (XXXI. cikk 6. pont). Természetesen Izrael a szabad belátása szerint hozzájárulhat egy újabb (a huszonkettedik) arab állam létrehozásához a saját maga terhére. Ez azonban engedménynek minősül a részéről, mivel nincsen olyan nemzetközi jogi norma, illetve előírás, ami őt ilyen joglemondásra kötelezné. Az, hogy mit hoz a jövő, a felek tárgyalásainak függvénye. Tény viszont, hogy a palesztin fél olyan súlyosan megsértette az osloi megállapodást, hogy azzal okot szolgáltatott Izraelnek akár a visszalépésre is a kötelezettségek alól.

A szerződések jogáról szóló 1969-es bécsi egyezmény 60. cikke a szerződés „lényeges megszegése” esetén feljogosítja a szerződésszegő féllel szemben a másik felet a szerződés teljes, vagy részbeni megszüntetésére, vagy alkalmazásának teljes, vagy részbeni felfüggesztésére. Ilyen lényeges

\footnotetext{
${ }^{55}$ A kép forrása: https://www.jewishvirtuallibrary.org/map-of-palestinian-autonomy (@ AICE).

${ }^{56}$ Ilyenek a területtel és a határokkal, az adott területen lévő zsidó településekkel, a biztonsági garanciákkal, a menekültekkel és a Jeruzsálemmel kapcsolatos kérdések.
} 
szerződésszegést jelent például „a szuerzoódés tárgyának és céljának megvalósitásához nélkülöz̧hetetlen rendelkezés megsértése" (60. cikk 3/b. pont).

Az Oslo II. megállapodás XXXI. cikkének 7. pontja előírja, hogy „az állandó státusæról sqoóló tárgyalások végéig egyike fél sem kę̧deményez olyan lépést, amely megváltoztatná Ciszjordánia, vagy a Gázai övezet státuszát”. Ennek ellenére a palesztin autonómia elnöke 2011 óta Izraelt megkerülve nemzetközi diplomáciai offenzívát folytat a palesztin államiság egyoldalú elismertetéséért. Így például a világszervezetben lévő tagállami státuszért folyamodott az ENSZ-hez. Ezt ugyan nem sikerült elérnie, de annyit igen, hogy az ENSz-ben „Palesztina” addig fennálló szimpla „megfigyelői” státuszát „nem tag megfigyelő államra” változtatták, az UNESCO-ba pedig teljes jogú tagként vették fel és az államok számára nyitva álló Nemzetközi Büntetőbíróság Statútumához való csatlakozását is befogadták. ${ }^{57}$ Mindemellett a Palesztin Autonómia nemzetközi szinten államként lép fel, számos országban úgynevezett nagykövetségeket tart fenn annak ellenére, hogy ilyen szintű külügyi hatáskört az autonómia szerződés nem ruházott rá. Ettől persze még nem minősül államnak, mert szervezetekben való tagsági státusz nem tudja pótolni az önálló államiság nemzetközi jogi kritériumainak való megfelelés hiányát.

\subsection{A palesztin önrendelkezési jog}

Az 1970-es évek óta, amióta a palesztinai arabok önálló, nevezetesen palesztin népnek deklarálták magukat, szüntelenül ismétlődő érv a népek önrendelkezési jogára és ennek körében a palesztin nép önrendelkezési jogára hivatkozni a ciszjordániai (júdea-szamariai), kelet-jeruzsálemi és gázai izraeli területi jogok elvitatása végett. Ez politikailag tetszetős érv, de másokat ennek elismerésére, illetve tűrésre kötelező jogi relevanciája éppoly kevésbé van, mint ahogy azt a közelmúltban a katalán, vagy korábban a kanadai, francia ajkú Quebec tartomány esetében láthattuk.

A nemzetközi jogban a népek önrendelkezési joga ${ }^{58}$ egy összetett és bizonytalan kérdéskör, több ok miatt is. ${ }^{59}$ Részben mert a tartalma többféleképpen is kifejezhetô, így az autonómia különböző formáiban vagy tagállami minőségben is. Csak az egyik, de egyáltalán nem magától értetődő formája az önálló, szuverén államiság. A nemzetközi jog nem ír elő, különösen nem tesz alanyi joggá egyetlen meghatározott önrendelkezési formációt sem. Az ENSz Alapokmánya elsődlegesen a tagállamok szuverenitásának és területi épsége védelmének elvére helyezkedik, ami

\footnotetext{
${ }^{57}$ Lásd MÉSZÁROS, Jogi háború Izrael ellen, https://www.hetek.hu/hit-es-ertekek/2020februar/jogi-haboru-izraelellen.

58 TóTH, A népek önrendelkezési joga, https://ijoten.hu/uploads/a-nepek-onrendelkezesi-joga.pdf.

${ }^{59} \mathrm{Az}$ első nemzetközi jogi dokumentum, amiben a népek önrendelkezési joga megjelent, az ENSz Alapokmánya (1. cikk 2. bekezdés és 55. cikk), de tartalmi meghatározás nélkül. Később az ENSZ Közgyúlése által 1966-ban megalkotott Polgári és Politikai Jogok Nemzetközi Egyezségokmánya, továbbá a Gazdasági, Szociális és Kulturális Jogok Nemzetközi Egyezségokmánya azonos szövegű 1. cikkének 1. bekezdése definiálta annak tartalmát: „e jog értelmében a népek szabadon határozzák meg politikai rendszerüket és szabadon biztositják gazdasági és kulturális fejlödésüket”". Azonban mindezek megvalósulásának az ENSZ Alapokmányának rendelkezéseivel összhangban kell állniuk (1. cikk 3. bekezdés). Ehhez viszont a tagállamok területi épségének és szuverenitásának védelme is hozzátartozik. Nem véletlen, hogy a Közgyưlés egy korábbi nyilatkozata, ami már megelőlegezte az önrendelkezési jog későbbi egyezménybe foglalását, kimondta, hogy „,bármely kissérlet, amely egy ország nemzeti egységének és terïleti integritásának részleges, vagy teljes feldarabolására törekszik, nem egyeztethetö össze az Egyesült Nemezetek. Alapokmányának céljaival és elveivel”. (ENSZ KGY 1960-ban alkotott 1514 (XV.) sz. Nyilatkozata a gyarmati országoknak és népeknek nyújtandó függetlenségről - 6. pont). Lásd hozzá CsÁNYI, A kisebbségvédelem és egyes jogi kérdései, http://jesz.ajk.elte.hu/csanyi20.htm.
} 
a népek önrendelkezési jogának is korlátot szab. Ha tehát egy nép olyan terület fölött kíván rendelkezni, ami fölött már egy korábbi állam szuverenitása érvényesül, akkor igényét e szuverén állammal való tárgyalások útján kell rendeznie, tudomásul véve a szuverén fél elsőbbségi pozíciójából eredő jogi és politikai következményeket. Ilyen módon a népek önrendelkezési jogának gyakorlása elsősorban politikai, nem pedig jogi kérdés. ${ }^{60}$

Másrészt az önrendelkezési jog kérdése nem ragadható ki a történeti kontextusból. Kifejezetten a gyarmati népek önállóvá válásának elősegítése volt a megfogalmazásának célja. Ebből folyik az a nemzetközi gyakorlat, ami szerint az önrendelkezési jog csak a gyarmati jogállásból való felszabaduláskor aktualizálódó szándéknyilvánításkor illeti meg az érintett népeket, a nemzetközi béke és biztonság fenntartása érdekében később a további osztódást már el kell kerülni. ${ }^{61}$

Ebben a vonatkozásban nem kerülhetô meg annak újra említése, hogy a palesztinai arab önrendelkezési jog már kielégítést nyert akkor, amikor a mandátum Jordán folyótól keletre elterülő nagyobbik részét a brit kettéválasztás jóváhagyásával a Népszövetség 1922-ben arab nemzeti otthonnak rendelte, aminek talaján 1946-ban meg is alakult az önálló palesztinai arab állam, Transzjordánia. Ezen felül mindaddig, amíg 1949 és 1967 között Ciszjordánia (Júdea-Szamaria), Kelet-Jeruzsálem és a Gázai övezet arab (jordániai és egyiptomi) kézben volt, maga Jordánia és Egyiptom sem hoztak létre ott önálló arab államot, sem pedig az Arab Liga nem szorgalmazott ilyen megoldást. De ami ennél is fontosabb, a helyi arab lakosság ekkor nem élt újabb, független palesztinai arab állam megalapítására irányuló igénnyel, önrendelkezési joggal, sőt éppen ellenkezőleg: a PFSZ alapító kartájában (1964) maga is kifejezetten deklarálta, hogy „nem gyakorol semmilyen regionális szuverenitást” az említett területek fölött. ${ }^{62}$ Ekkor még a helyi arabok nem tartották magukat a környező arab országok arabságától különálló önálló etnikumnak sem, és a palesztin jelzőt földrajzi értelemben használták, ${ }^{63}$ ami csak az 1967-es arab-izraeli háború után változott meg, amikor az említett területek Izrael igazgatása alá kerültek. Ez a trend az újabb, jom kippuri arabizraeli háború (1973) háború után erősödött fel, amikor nyilvánvalóvá vált, hogy a területek izraeli fennhatóság alatt maradnak.

A palesztinai arabok önrendelkezési jogát azonban Izrael mindezek ellenére is elismerte az osloi megállapodásban azzal, hogy részükre már a végleges rendezésig is területi autonómiát engedett a kérdéses területeken a „C” övezet kivételével. Izrael saját belátására tartozik, hogy merre kíván innét lépni, semmiféle nemzetközi jogi kötelezettsége nincsen ebben a vonatkozásban. Mindennek megtárgyalása közvetlenül az érintett felek dolga.

\footnotetext{
${ }^{60}$ Ez a kérdéskör nem keverendő a nemzeti és etnikai kisebbségek nemzetközi jogi védelmének témakörével.

${ }^{61}$ Ezt a koncepciót tartalmazza „Az államok baráti kapcsolatait sqabályozó nemzettööri jogi elvekeról” szóló ENSz Közgyúlési Nyilatkozat is: General Assembly Resolution 2625 (XXV), adopted on 24 October 1970. Declaration on Principles of International Law concerning Friendly Relations and Cooperation among States in accordance with the Charter of the United Nations (24 October 1970), https://www.un.org/ruleoflaw/files/3dda1f104.pdf.

62 Az 1964. évi Palesztin Nemzeti Karta 24. pontját lásd Dokumentumok a Közel-Kelet XX. századi történetéhez 396397.

${ }^{63}$ Jellemző, hogy azokat a zsidókat is palesztinoknak nevezték, akik „palesztinai származásúak”, 1964. évi Palesztin Nemzeti Karta 6-7. pontok, lásd Dokumentumok a Közel-Kelet XX. századi történetéhez 396-397.
} 


\section{Következtetések}

Az izraeli-arab viszony és ezen belül az úgynevezett palesztin-kérdés rendezése nyilvánvalóan jóval összetettebb annál, hogy pusztán nemzetközi jogi alapon lehetne megközelíteni. Ez azonban nem jelenti azt, hogy ne kellene figyelemmel lenni a nemzetközi jog előírásaira is, azt meg különösen nem, hogy meghamisítsák azokat, vagy velük szemben politikai nyilatkozatokat tüntessenek föl nemzetközi jogként.

A san remoi megállapodás tekintetében a fentiek alapján hét állítás fogalmazható meg.

(1) Izrael mai szuverén államának nemzetközi jogi alapjai visszanyúlnak az ENSz Közgyúlés 1947. november 29-i felosztási javaslata elé, a száz éve létrejött san remoi megállapodásig, ami zsidó nemzeti otthon létesítését írta elő a palesztinai mandátum céljaként.

(2) Annak területét az 1922. évi palesztinai brit népszövetségi mandátumszerződés jelölte ki a mandátumterület keleti és nyugati részének belső elkülönítésével a Jordán folyónak az Akabaiöböl északi csücskéig meghosszabbított vonalától a Földközi-tengerig („,folyótól a tengerig”) terjedő teljes területre, aminek máig ható következményei vannak az idetartozó területrészek birtoklására vonatkozó jogcímek vonatkozásában.

(3) Az ENSz Közgyúlés 1947-es felosztási javaslata az arab elutasítás következtében nem írta felül a korábbi területfelosztást, ezért a modernkori izraeli állam a fentírt („folyótól a tengerig” terjedő teljes) földterületre feljogosító korábbi, belső mandátumi határokra alapozva jött létre, amit az uti possidetis juris és az estoppel nemzetközi jogelvei is megerősítenek.

(4) Ez a helyzet a tanulmány írásakor is fennáll, mivel mind a mai napig nem született a korábbi mandátumi területfelosztást joghatályosan felülíró nemzetközi jogi rendezés.

(5) Ebből következik, hogy Ciszjordánia (Júdea-Szamaria) területének birtoklására, akár teljes terjedelmére, Izraelnek a mai napig is érvényes nemzetközi jogi jogcíme van. Ez vonatkozik Kelet-Jeruzsálemre is.

(6) Ezért Ciszjordánia (Júdea-Szamaria) vonatkozásában izraeli annektálásról fogalmilag akkor sem lehet beszélni, ha arra Izrael a joghatóságának teljességét kiterjeszti, mert a kérdéses terület - mint ahogy Kelet-Jeruzsálem sem - a brit mandátum óta sosem képezte jogszerúen más állam területét, a palesztinokét már csak azért sem, mert ilyen állam ott korábban nem volt, és a jelen tanulmány írásakor sem létezik.

(7) Mindez nem akadályozza Izraelt abban, hogy a kérdéses területek fölött őt illető szuverenitásból eredően azok igazgatására - szabad belátása szerint és mértékben - jogokat ruházzon át, mint tette ezt a palesztin területi autonómiát létrehozó Oslo I-II. megállapodásokban. Ebből azonban nem következik törvényszerűen palesztin állam, mivel ilyet sem az osloi megállapodás nem tartalmaz, sem arra vonatkozó nemzetközi jogi kötelezettség nem létezik jelenleg.

A száz éve San Remoban született nemzetközi megállapodás és az arra alapozott palesztinai brit népszövetségi mandátumszerződés máig ható jogkövetkezményeitől tehát nem lehet és nem is szabad eltekinteni. 


\section{Felhasznált források és irodalom}

ABU Jaber, Kamel S.: Transjordan, the Hashimite Kingdom and the Palestine war. In: Encyclopaedia Britannica, https://www.britannica.com/place/Jordan/Transjordan-the-Hashimite-Kingdom-and-the-Palestine-war (letöltve: 2020. 08. 04.)

Advisory Opinion on the Legal Consequences for States of the Continued Presence of South Africa in Namibia (South West Africa) notwithstanding Security Council resolution 276 (1970), https://www.icj-cij.org/files/caserelated/53/053-19710621-ADV-01-00-BI.pdf (letöltve: 2020. 08. 04.)

AHARONI, Johanan - Avi-YONAH, Michael: Bibliai atlasz. (A magyar nyelvú kiadást szerkesztette: GRÜLL Tibor HoRVÁTH András). Jeruzsálem - Budapest 1999

Bell, Abraham - Kontorovich, Eugene: Palestine, Uti Possidetis Juris and the Borders of Israel. Arizona Law Review, vol. 58:633, https://arizonalawreview.org/pdf/58-3/58arizlrev633.pdf (letöltve: 2020. 08. 04.)

Ben-Sasson, Haim Hillel (szerk.): A History of the Jewish People. Cambridge1976

COTTIER, Thomas - MÜLLER, Jörg Paul: Estoppel. Oxford Public International Law. https://opil.ouplaw.com/view/10.1093/law:epil/9780199231690/law-9780199231690-e1401 (letöltve: 2020. 08. 04.)

CSÁNYI Edina: A kisebbségvédelem és egyes jogi kérdései 1. Jogelméleti szemle 2004/4. http://jesz.ajk.elte.hu/csanyi20.html (letöltve: 2020. 08. 04.)

De BLoIs, Matthijs - TuCKER, Andrew: Israel on Trial - How International Law is Being Misused to Delegitimize the State of Israel. Soest 2018

DE BloIs, Matthijs - TuCKER, Andrew: Are the Israeli Settlements in the West Bank Illegal under International Law? THINC. The Hague Initiative for International Cooperation 2017 https://www.thinc.info/wp-content/uploads/2017/06/thinc-INT-brochure_22june17_small.pdf (letöltve: 2020. 08. 04.)

DE BLoIs, Matthijs - TuCKER, Andrew: The Status of Jerusalem. THINC. The Hague Initiative for International Cooperation 2018

https://www.thinc.info/wp-content/uploads/2018/08/The-Status-of-Jerusalem_20180802.pdf (letöltve: 2020. 08. 04.)

Declaration of Principles on Interim Self-Government Arrangements https://web.archive.org/web/20021115183950/http://knesset.gov.il/process/docs/oslo_eng.htm (letöltve: 2020. 08. 04.)

Declaration on Principles of International Law concerning Friendly Relations and Cooperation among States in accordance with the Charter of the United Nations (24 October 1970), https://www.un.org/ruleoflaw/files/3dda1f104.pdf. (letöltve: 2020. 08. 04.)

DERSHOWITZ, Alan: Izrael védelmében. Budapest 2016

GAUTHIER, Jacques Paul: Sovereignty over the Old City of Jerusalem: A Study of the Historical, Religious, Political and Legal Aspects of the Old City. Geneva 2007

General Assembly Resolution 2625 (XXV), adopted on 24 October 1970. Declaration on Principles of International Law concerning Friendly Relations and Cooperation among States in accordance with the Charter of the United Nations (24 October 1970), https://www.un.org/ruleoflaw/files/3dda1f104.pdf (letöltve: 2020. 08. 04.)

GILBERT, Martin: The Routledge Atlas of the Arab-Israeli Conflict (8. kiadás). London - New York 2005

GOLD, Dore: From „occupied territories” to „disputed territories”. Jerusalem Letter / viewpoints. No. 4703 Shvat 5762 / 16 January 2002, http://www.jcpa.org/jl/vp470.htm (letöltve: 2020. 08. 04.)

GOLD, Dore: The Fight for Jerusalem: Radical Islam, the West, and the Future of the Holy City. Washington DC 2007

GRIFF, Howard: The Legal Foundation and Borders of Israel under International Law - A Treatise on Jewish Sovereignty over the Land of Israel. Jerusalem 2008

GRÜLL Tibor: Bibliai történelem. Ószövetség. Budapest 2019 
GRÜLL Tibor: Áruló vagy megmentő? Flavius Josephus élete és művei. Budapest - Pozsony 2010

GRÜLL Tibor: „Ézsau három könnycseppje”. A zsidók három háborúja Róma ellene (Kr. u. 66-136.). Msc. Budapest 2015, http://real-d.mtak.hu/885/7/dc_1109_15_doktori_mu.pdf (letöltve: 2020. 08. 04.)

HAETZnI-CoHen, Sarah: Why Israeli Rule in the West Bank Is Legal under International Law - An interview with Professor Eugene Kontorovich. Jerusalem Center for Public Affairs, April 8, 2018

https://jcpa.org/why-israeli-rule-in-the-west-bank-is-legal-under-international-law/ (letöltve: 2020. 08. 07.)

Helmreich, Paul C.: From Paris to Sèvres. The partition of the Ottoman Empire at the Peace Conference of 1919-1920. Columbus 1974

HofmanN, Rainer: Annexation. In: Oxford Public International Law https://opil.ouplaw.com/view/10.1093/law:epil/9780199231690/law-9780199231690-e1376 (letöltés: 2020. 08. 04.)

Interim Agreement on the West Bank and the Gaza Strip, https://www.jewishvirtuallibrary.org/interim-agreementon-the-west-bank-and-the-gaza-strip-oslo-ii (letöltve: 2020. 08. 04.)

International Court of Justice on South West Africa Cases (Judgement of 21-XII-62), https://www.icj-cij. org/files/case-related/46/046-19621221-JUD-01-00-BI.pdf (letöltve: 2020. 08. 04.)

J. NAGY László: Az ummától a nemzetállamig. Az arab országok története a 19-20. században. Szeged 2009

Jogászok Hágai Nyilatkozata az izraeli-palesztin konfliktusról / The Hague Statement of jurists on the Israel-

Palestine conflict. THINC. The Hague Initiative for International Co-operation 2017

magyar: https://www.thinc.info/jogaszok-hagai-nyilatkozata-az-izraeli-palesztin-konfliktusrol/

angol: https://www.thinc.info/wp-content/uploads/2017/12/The-Hague-Statement_XE_20171130-1.pdf (letöltve: 2020. 08. 04.)

KÁDÁR József (fordította és sajtó alá rendezte): Az 1949-es izraeli-transzjordániai fegyverszüneti tárgyalások dokumentumai. Documenta Historica 97. Szeged 2016

Kende Tamás - NAgy Boldizsár - SONNEVEND Pál - VALKi László (szerk.): Nemzetközi jog. Második, átdolgozott kiadás. Budapest 2018

KovÁCs Péter: Nemzetközi közjog. Budapest 2011

KOVÁCs Péter: Ítélet tanácsadó vélemény köpönyegében - avagy van-e harmadik típusú eljárás a Nemzetközi Bíróság előtt?- Széljegyzetek a Nemzetközi Bíróságnak a palesztinai területen épített fal tárgyában adott tanácsadó véleményéhez. Iustum Aequum Salutare IV. 2008/1. 5-22. http://ias.jak.ppke.hu/hir/ias/20081sz/01.pdf (letöltve: 2020. 08. 07.)

LAQUEUR, Walter - RUBIN, Barry (szerk.): The Israel - Arab Reader. A Documentary History of the Middle East Conflict (6. átdolgozott kiadás). Penguin Books 2001

LEWIN, Ariel: The Archaeology of Ancient Judea and Palestine. Los Angeles 2005

LLOYD GeOrge, David: The Truth About the Peace Conference II. London 1938

LUGOSI Győző (szerk.): Dokumentumok a Közel-Kelet XX. századi történetéhez. Szöveggyűjtemény. Budapest 2006

MÉSZÁROS István László: Egy nemzet feltámasztása - Száz éve született nemzetközi döntés a zsidó nemzeti otthon helyreállításáról. Hetek 2020. 04. 23.

https://www.hetek.hu/kulfold/2020aprilis/egy-nemzet-feltamasztasa (letöltve: 2020. 08. 04.)

MÉSZÁros István László: The Two-State Solution - objections under International Law. THINC. The Hague Initiative for International Co-Operation (January 17, 2020)

https:/ / www.thinc.info/the-two-state-solution-objections-under-international-law/ (letöltve: 2020. 08. 04.)

MÉSZÁros István László: Jogi háború Izrael ellen. Hetek 2020. 02. 28. https://www.hetek.hu/hit-es-ertekek/2020februar/jogi-haboru-izrael-ellen (letöltve: 2020. 08. 04.)

MÉSZÁROS István László: A palesztin állam mítosza. Hetek 2020. 02. 07. https://www.hetek.hu/hit-es-ertekek/2020februar/palesztin-allam-mitosza (letöltve: 2020. 08. 04)

Minutes of Palestine Meeting of the Supreme Council of the Allied Powers held in San Remo at the Villa Devachan https://upload.wikimedia.org/wikipedia/commons/f/f7/Minutes_of_the_1920_Conference_of_San_ Remo.pdf (letöltve: 202. 08. 07.) 
Montevideo Convention on the Rights and Duties of States (1933)

https://www.jus.uio.no/english/services/library/treaties/01/1-02/rights-duties-states.xml (letöltve: 2020.08.04)

Rome Statute of the International Criminal Court, https://www.icc-cpi.int/resource-library/documents/rs-eng.pdf (letöltve: 2020. 08. 04.)

San Remo Resulution, https://www.jewishvirtuallibrary.org/the-san-remo-conference (utolsó letöltés: 2020. 08. 04.)

South-West Africa Cases; Advisory Opinion Concerning the International Status, International Court of Justice (ICJ), 11 July 1950, https://www.refworld.org/cases, ICJ,4028e9d44.html (letöltve: 2020. 08. 04.)

STEIN, Leonard: The Balfour Declaration. New York 1961

The Anglo American Treaty of 1924, http:/ israelinternationallaw.blogspot.com/2015/12/the-anglo-american-treatyof-1924.html (letöltve: 2020. 08. 04.)

The Palestine Mandate, https://avalon.law.yale.edu/20th_century/palmanda.asp (letöltve: 2020. 08. 04.)

TÓтH Norbert: A népek önrendelkezési joga. IJOTEN https://ijoten.hu/uploads/a-nepek-onrendelkezesi-joga.pdf (letöltve: 2020. 08. 04.)

UN General Assembly Resolution 181 (II.) Future government of Palestine, November 29, 1947 https://unispal.un.org/DPA/DPR/unispal.nsf/0/7F0AF2BD897689B785256C330061D253 (letöltve: 2020. 08. 04.)

UN General Assembly Resolution 3314 (XXIX), https://undocs.org/en/A/RES/3314(XXIX) (letöltve: 2020. 08. 04.)

UN General Assembly Resolution 242 (1967) https://undocs.org/S/RES/242(1967) (letöltve: 2020. 08. 04.)

VALKI László: A fal, Hágából nézve. Élet és Irodalom 2004. augusztus 13. http://www.grotius.hu/doc/pub/FZHCJH/2013-06-27_valki_laszlo_a-fal-hagabol-nezve.pdf (letöltve: 2020. 08. 04.)

VALKI László: Az államelismerés, mint jogi fegyver - Jugoszlávia felbomlásának tanulságai. Külügyi Szemle 2002/2. 121-142. https://library.hungaricana.hu/hu/view/KULUGY_KulugyiSzemle_2002/?pg=371\&layout=s (letöltve: 2020. 08. 04.)

VOYIAKIS, Emmanuel: Estoppel. In: Oxford Bibliographies https://www.oxfordbibliographies.com/view/document/obo-9780199796953/obo-97 80199796953-0058.xml (letöltve: 2020. 08. 04.)

A felhasznált képek forrása

1. kép: https://www.jewishvirtuallibrary.org/map-of-the-twelve-tribes-of-israel-2 (letöltve: 2020. 08. 04.)

2. kép: https://www.jewishvirtuallibrary.org/map-of-the-kingdom-of-david-and-solomon, Israeli Ministry of Foreign Affairs (letöltve: 2020. 08. 04.)

3. kép: https://www.jewishvirtuallibrary.org/map-of-jewish-national-home-determined-by-san-remo-conference1920, Israeli Ministry of Foreign Affairs (letöltve: 2020. 08. 04.)

4. kép: https://www.jewishvirtuallibrary.org/map-of-the-british-mandate-1921-1923, Israeli Ministry of Foreign Affairs (letöltve: 2020. 08. 04.)

5. kép: https://en.wikipedia.org/wiki/United_Nations_Partition_Plan_for_Palestine\#/media/File:UN_Palestine_ Partition_Versions_1947.jpg (letöltve: 2020.08. 04.)

6. kép: https://www.jewishvirtuallibrary.org/armistice-lines-map-1949, Israeli Ministry of Foreign Affairs (letöltve: 2020. 08. 04.)

7. kép: https://www.jewishvirtuallibrary.org/map-of-the-cease-fire-lines-after-the-six-day-war-june-1967, Israeli Ministry of Foreign Affairs (letöltve: 2020. 08. 04.)

8. kép: https://www.jewishvirtuallibrary.org/map-of-palestinian-autonomy, IRIS (Information Regarding Israel's Security) (letöltés: 2020. 08. 04.) 